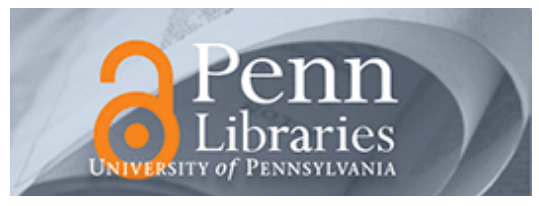

University of Pennsylvania

ScholarlyCommons

Management Papers

Wharton Faculty Research

6-1-2017

\title{
These Unequal States: Corporate Organization and Income Inequality in the United States
}

\author{
J. Adam Cobb \\ University of Pennsylvania \\ Flannery G. Stevens \\ University of Utah
}

Follow this and additional works at: https://repository.upenn.edu/mgmt_papers

Part of the Management Sciences and Quantitative Methods Commons

\section{Recommended Citation}

Cobb, J., \& Stevens, F. G. (2017). These Unequal States: Corporate Organization and Income Inequality in the United States. Administrative Science Quarterly, 62 (2), 304-340. http://dx.doi.org/10.1177/ 0001839216673823

This paper is posted at ScholarlyCommons. https://repository.upenn.edu/mgmt_papers/236

For more information, please contact repository@pobox.upenn.edu. 


\title{
These Unequal States: Corporate Organization and Income Inequality in the United States
}

\begin{abstract}
In an analysis of data on employment in the 48 contiguous United States from 1978 to 2008, we examine the connection between organizational demography and rising income inequality at the state level. Drawing on research on social comparisons and firm boundaries, we argue that large firms are susceptible to their employees making social comparisons about wages and that firms undertake strategies, such as wage compression, to help ameliorate their damaging effects. We argue that wage compression affects the distribution of wages throughout the broader labor market and that, consequently, state levels of income inequality will increase as fewer individuals in a state are employed by large firms. We hypothesize that the negative relationship between large-firm employment and income inequality will weaken when large employers are more racially diverse and their workers are dispersed across a greater number of establishments. Our results show that as the number of workers in a state employed by large firms declines, income inequality in that state increases. When these firms are more racially diverse, however, the negative relationship between large-firm employment and income inequality weakens. These results point to the importance of considering how corporate demography influences the dispersion of wages in a labor market.
\end{abstract}

\section{Keywords}

employment, firm boundaries, income inequality, social comparisons, wage compression

\section{Disciplines}

Management Sciences and Quantitative Methods 


\title{
THESE UNEQUAL STATES: CORPORATE ORGANIZATION AND INCOME INEQUALITY WITHIN THE UNITED STATES
}

\begin{abstract}
Focusing on the United States, we examine the connection between organizational demography and rising income inequality at the state level. Drawing upon research on social comparisons and firm boundaries, we argue that large firms are particularly susceptible to invidious social comparisons and undertake strategies, such as wage compression, to help ameliorate their damaging effects. We argue that wage compression affects the distribution of wages throughout the broader labor market and that, consequently, state levels of income inequality will increase as fewer individuals in a state are employed by large firms. We also argue that the negative relationship between large-firm employment and income inequality will weaken when large employers are more racially diverse and when their workers are dispersed across a greater number of establishments. Using pooled, cross-sectional data at the state level, our results show that, net of other factors, as the number of workers in a state employed by large firms declines, income inequality in that state increases. However, when these firms are more racially diverse, the negative relationship between large-firm employment and income inequality weakens. These results point to the importance of considering how corporate demography influences the dispersion of wages in a labor market.
\end{abstract}


How economic rewards in a society are distributed is a central question of the social sciences and, in attempts to answer it, scholars from a variety of disciplines have developed several theories. For example, human capital approaches emphasize that income differentials are the result of unequal endowments in productive capacities among individuals (e.g., Becker, 1964; Goldin and Katz, 2008). Structuralist theories, conversely, suggest that wage differentials between individuals arise from differences in the industries and sectors in which they are employed (e.g., Beck, Horan, and Tolbert, 1978). Meanwhile, other scholars have turned their attention to the ways in which firms affect the distribution of income. Because wages are often tied to jobs rather than to individuals (Granovetter, 1981), and because the pricing and allocation of labor are often governed by administrative rules rather than market forces (Doeringer and Piore, 1971), advocates of this approach contend that, to understand how rewards in a society are distributed, one must examine decisions made by employers regarding the allocation of money, opportunity, and status (Baron, 1984; Bidwell et al., 2013).

Despite the significant contributions of the organizational research on inequality, few studies to date have examined how firms affect income inequality in the broader labor market (Sørensen, 2007). Rather, most studies in this area have focused on explaining patterns of inequality within organizations (e.g., Kalleberg and Van Buren, 1994). While an important area of inquiry, singular attention to intra-organizational inequality may mask the broader impact of employer choices regarding how to structure employment relations. For instance, strategies that likely decrease within-firm income inequality, such as outsourcing and layoffs, may increase societal-level inequality (Cobb, 2016). Hence, although an organizational approach to the study of income inequality holds great promise, we still lack a robust understanding of the ways in which firms affect the distribution of income in a labor market (Sørensen and Sorenson, 2007). 
To help address this concern, we leverage insights from research on the firm-size wage effect (e.g., Oi and Idson, 1999), social comparisons and firm boundaries (e.g., Nickerson and Zenger, 2008), and organizational wage-setting (e.g., Granovetter, 1981) to develop a simple theory about how changes in corporate employment affect rates of income inequality in a labor market.

Our core argument is that rates of income inequality are affected by the extent to which workers in a labor market are employed by large firms. Prior research has found that otherwise identical workers earn more when working for large firms - a phenomenon referred to as the firm-size wage effect (FSWE) — and that the FSWE is greater for low-skilled workers than for high-skilled workers (Hollister, 2004). By paying lower-skilled workers a greater wage premium than higher-skilled ones, large firms compress wages. One rationale for why large firms are apt to do so is to reduce the costs of social comparisons. Research contends that workers are prone to compare their rewards to those received by similar others (Festinger, 1954; Adams, 1963) and that employee responses to any perceived inequity arising from these evaluations impose costs on the firm (Cohn et al., 2014). To minimize these costs, firms may attempt to establish a sense of internal pay equity by compressing wages. Because social comparison costs increase with the scale and scope of the firm (Nickerson and Zenger, 2008), large firms should be more likely than smaller firms to compress wages. On average across large firms, the wages for lower-skilled workers are higher than the going market wage and wages for higher-skilled workers are at or below the going wage. This leads us to expect that the overall distribution of wages in a labor market will be narrower when more workers are employed by large firms.

If large firms compress wages at least in part to minimize their social comparison costs, factors that affect the strength of social comparison processes within large firms should moderate the relationship between large-firm employment and income inequality. Prior research has 
suggested that people will select as referents those who belong to the same social categories and those about whom they have greater information (Lansberg, 1989). As such, we posit that, when the large corporate employers in a state are more racially diverse and when their employment is more dispersed across establishments, firms will have greater leeway in differentiating rewards across groups of workers, weakening the relationship between large-firm employment and levels of income inequality in the labor market.

We test our hypotheses on the contiguous 48 U.S. states from 1978 to 2008. While research has found abundant evidence indicating that income inequality in the United States grew dramatically during this period (Atkinson, Piketty, and Saez, 2011), this growth has been highly uneven within the U.S. states. As measured by the Gini coefficient, states such as Arkansas, Florida, New York, and South Carolina experienced a growth in inequality of over 50 percent during the period, while Colorado, Delaware, Minnesota, and South Dakota had less than 38 percent growth. Because changes in income inequality and corporate demography are not uniform within states over time, we can exploit this variation to examine the impact of large-firm employment on state levels of income inequality. Through a detailed analysis, we show that, net of other factors - including labor force size, educational attainment, globalization, unionization, political party influence, minimum wage and tax rates, governmental transfers, and rates of innovation—state levels of income inequality increase as fewer individuals in the state are employed by large firms. However, this negative relationship weakens when those firms are more racially diverse. By providing evidence that corporate demography affects state rates of income inequality, our study answers calls to analyze how firms influence broader labor market outcomes (see Baron and Bielby, 1980; Sørensen, 2007; Kalleberg, 2009; Pfeffer, 2010).

\section{EXPLAINING INCOME INEQUALITY}


A number of reviews on income inequality have been conducted (e.g., Levy and Murnane, 1992; Katz and Autor, 1999; McCall and Percheski, 2010), so we cover the literature briefly. Most research on income inequality focuses on either market- or institutional-based explanations for its rise. Building from the human capital tradition, the most popular marketbased explanation, skill-biased technological change (SBTC), contends that the adoption and use of many types of information and communication technologies (ICTs) increases the marginal productivity of higher-skilled workers while leaving unchanged (or potentially lowering) the marginal productivity of lower-skilled workers (Autor, Katz, and Kearney, 2008). Much of the early study of inequality and globalization, another market-based account, focused on trade flows, speculating that as less-developed countries integrate into the world economy, the demand for and returns to unskilled labor increase in those countries, reducing income disparities. Conversely, the demand for high-skilled labor in developed countries increases while the demand for low-skilled labor declines, exacerbating disparities (Bentele and Kenworthy, 2013).

The most popular institutional account of rising income inequality is declining rates of unionization. This body of research argues that collective bargaining raises wages among lesseducated workers, thereby reducing inequalities between occupations while standardizing wages within firms and industries (Western and Rosenfeld, 2011). Other institutional factors have also been examined, such as occupational structure (e.g., Mouw and Kalleberg, 2010), financialization (e.g., Lin and Tomaskovic-Devey, 2013), government policy (e.g., Kenworthy and Pontusson, 2005), and family formation practices (see McCall and Percheski, 2010). Each of these has proven to be an important influence on the distribution of income in the United States.

Because of the complexity of the phenomenon, it stands to reason that there is no single explanation for why income inequality has been rising at different rates across U.S. states. While 
each of the aforementioned theories has provided useful insights, we aim to complement and extend this prior work by paying direct attention to the role of employers, who are the relevant actors providing unequal access to economic rewards and opportunities (Kalleberg and Sørensen, 1979). Though previous studies have found that employer wage variation accounts for a significant part of the overall variance in worker wages (e.g., Song et al., 2015), no single theoretical source for these differentials has gained consensus to date. In the section below, we explain how the presence of large employers and the social comparison processes occurring within their bounds may affect income inequality in the broader labor market.

\section{SOCIAL COMPARISON, CORPORATE ORGANIZATION, AND INEQUALITY} Social Comparison and Wage Compression within Firms

One of the most consistent findings in the research on employment and compensation is that otherwise identical workers earn more when working for large firms. Numerous theories for this empirical regularity have been proposed, including differences related to firm size in information acquisition and monitoring costs, technology, organizational characteristics, and union threats, among others (see Oi and Idson, 1999). Though researchers in this area have primarily focused on examining the causes of the FSWE, the distributional consequences of the FSWE have been largely unexplored. Yet research has found evidence that large-firm employment is particularly rewarding to lower-skilled workers who receive an even greater wage premium than higher-skilled ones (Hollister, 2004). These findings suggest that whatever factors lead large firms to offer premium wages, the motivation to do so is stronger for lower-skilled, lower-wage workers, leading firms to compress wages. One factor that might explain why large firms compress wages in this manner is to reduce the costs that arise from perceptions of inequity that occur when rewards inside a firm are widely dispersed. 
To develop our theory for why large firms compress wages, we begin with the assumption that individuals compare their rewards to those received by a set of salient referents, as established in early research on social comparisons (Festinger, 1954; Adams, 1963). Individual motivation is influenced by perceptions of fairness or inequity arising from such comparisons, and, complicating this process, individuals tend to overestimate their performance (Weinstein, 1980; Larkin, Pierce, and Gino, 2012) and compare their rewards to those who are similar in (perceived) performance but receive greater rewards (Martin, 1981). Individuals engage in tactics to address these perceptions of inequity, such as reducing their effort (Cohn et al., 2014), lobbying managers who assign compensation (Milgrom and Roberts, 1988), leaving the collective (Carnahan, Agarwal, and Campbell, 2012), or otherwise engaging in counterproductive behaviors that are costly for the group (Gino and Pierce, 2010). We refer to these resulting costs as social comparison costs (Nickerson and Zenger, 2008).

While social comparisons can arise in any group, prior literature has established that similarity, proximity, the degree of interaction, and the availability of information are key determinants of employee selections of salient referents (Festinger, 1954; Kulik and Ambrose, 1992). In the marketplace, individuals have little personal contact and less information about the rewards of others, making social comparisons across firm boundaries more difficult (Akerlof and Yellen, 1988). As such, firm boundaries serve as a natural reference point for employees who are more sensitive to pay differences within a firm than between firms.

We also assume that the social comparison costs increase with the scale and scope of the firm, such that these costs are proportionately greater in larger firms than in smaller ones (Nickerson and Zenger, 2008). That is, while individuals compare their rewards to those of others irrespective of firm size, the costs that accrue from the perceived inequities arising from 
these comparisons should be proportionally greater in large firms. There are at least two reasons to believe that this assumption will hold. First, as the number of employees in a firm increases, we can reasonably expect that the disparity between the most and least productive workers also increases. If workers earned a wage equal to their marginal product, ${ }^{1}$ the disparity in performance and thus wages should exacerbate their propensity to engage in invidious social comparisons. Second, large firms are typically more complex and differentiated (Kalleberg and Van Buren, 1996), forcing them to integrate activities that vary in their average marginal products. Workers within these different activities then become part of each other's reference group, raising the potential for perceived inequities (Nickerson and Zenger, 2008).

Given the disruptive nature of social comparisons and their propensity to arise within (larger) organizations, a key task for a firm's executives is to structure the organization in a way that forms the desired bundle of human assets while minimizing governance and social comparison costs (Zenger and Huang, 2009). A number of scholars have suggested that one of the key ways in which organizational leaders respond to social comparison costs is by weakening the link between pay and performance (e.g., Akerlof and Yellen, 1988). Orthodox economic theory predicts that wages are likely to be based on the relative quality of workers—evidenced by performance, skills, and credentials—as well as on the broader market forces of supply and demand. Wage-setting systems that reward workers based on their marginal product can lead to higher levels of wage dispersion within organizations since they increase the wage gap between more and less productive workers (Bandiera, Barankay, and Rasul, 2007). Because objective, observable, and nonsocial standards for performance assessments are often lacking in

\footnotetext{
${ }^{1}$ Throughout, we make reference to pay being determined by worker productivity. We are agnostic, however, regarding whether wages are a true reflection of worker productivity, which is difficult to measure, or an outcome of social processes that influence perceptions of worker value (see Avent-Holt and Tomaskovic-Devey, 2014). Here we are concerned only with the going wage in the labor market rather than what factors determine that wage.
} 
organizational settings (Larkin et al., 2012) and because individuals have a proclivity to overestimate their abilities (Zenger, 1992), paying individuals differently for the same job will likely exacerbate the costs of social comparisons.

In practice, wages are often tied to jobs rather than to individuals (Granovetter, 1981). Historically, large corporate employers systemized the wage-setting process through job evaluation. In a prototypical job evaluation system, each job is evaluated along dimensions such as the required skill, effort, scope of responsibility, and working conditions (Boxall and Purcell, 2011). Jobs are then assigned wages based on their value to the firm and in relation to other jobs within the organization. To ensure consistency and avoid conflict, pay increases are restricted within modest ranges (Beer, Spector, and Lawrence, 1984). One of the consequences of these types of systems is that they "bend the market wages for each job—raising some and lowering others..." (Cappelli, 2001: 227), reducing wage dispersion within firms in comparison to the hypothesized marginal product schedule (Sanchez and Levine, 2012). By assigning wages to jobs and establishing criteria by which jobs are compared, employers hope to mitigate perceptions of inequity (Pfeffer and Davis-Blake, 1992). Not surprisingly, studies on wage-setting inside large firms confirm that a weak link exists between performance measures and pay and that nonperformance-related factors such as worker age, tenure, and job grade explain most of the variance in pay (e.g., Brown and Medoff, 1989). While workers may feel that their efforts merit greater pay, they cannot dispute the procedural fairness of these systems and have little recourse in appeals to management to adjust their pay (Zenger and Huang, 2009).

Forming a sense of internal pay equity requires employers to compress pay along two dimensions. First, horizontal compression occurs when those in the same job receive relatively equal pay even if their marginal products vary greatly. Job evaluation systems have been shown 
to create only modest wage variation among employees doing the same job (O'Shaughnessy, Levine, and Cappelli, 2001). Second, vertical compression occurs when pay differentials across jobs are flattened, despite the varying marginal products associated with those positions. Flattening differentials between jobs requires that the firm pay above the marginal product for some employees, typically lower-skilled, lower-wage workers, and/or pay near or below the marginal product for other workers, typically higher-skilled, higher-wage ones (Groshen, 1991). While wage compression may be employed as a strategy to lower social comparison costs, there may be other reasons large firms compress wages. For example, some researchers speculate that large firms are likely to pay above-market wages to help stave off unionization attempts (e.g., Mellow, 1982). In the United States many types of professional workers have historically not joined labor organizations (Lichtenstein, 2002). For this reason, we might expect that wage premiums resulting from unionization threats would be greater for low- to mid-skill workers. Prior research also suggests that large firms offer premium wages because monitoring and screening costs are higher (Garen, 1985). If these costs vary within the firm such that they are disproportionately higher for the lower-skilled workers, large firms may have a more compressed wage distribution than smaller firms. Thus, wage compression may be due, in part, to the efficiency gains firms receive from standardizing wages across jobs.

Though there may be multiple rationales for why large firms compress wages, a vast interdisciplinary literature supports the idea that large firms do so to foster perceptions of equity and to lower social comparison costs (e.g., Baker, Jensen, and Murphy, 1988; Lazear, 1989; Groshen and Levine, 1998; Larkin et al., 2012). Additionally, research on internal labor markets (ILMs) suggests that one of the overriding goals of organizational wage-setting policies is to use administrative procedures that help foster perceptions of equity and fairness (Doeringer and 
Piore, 1971). The literature on wage systems based on job evaluations similarly argues that such systems are designed specifically to ensure a more equitable and procedurally fair distribution of wages inside firms (Bartling and von Siemens, 2010). Moreover, there is little empirical support for the hypotheses that union threats, monitoring costs, and information-acquisition costs are responsible for compressed wages (see Brown and Medoff, 1989; Cappelli and Chauvin, 1991). While we cannot definitively rule out whether these or other alternative rationales explain why large firms are more likely to compress wages, the desire to maintain perceptions of equity seems to be a key reason behind such wage-setting systems.

\section{Social Comparison, Wage Compression, and Firm Boundaries}

During the period of the current study, large U.S. corporations also undertook a variety of tactics that helped redraw firm boundaries. Notably, as a result of divestitures, spin-offs, and other forms of restructuring associated with de-conglomeration, the relative size of the largest employers declined. In contrast to the 16.2 million workers employed by the Fortune 500 firms in 1979, only 11.5 million were employed by the Fortune 500 in 1993 (Useem, 1996). One of the primary motivations for the breakup of these conglomerates was that it was expected to increase the variation in performance across firm sub-units (Jensen, 1993) and that the less profitable subunits would no longer be subsidized by the more profitable ones. If these diversified business units varied in terms of their average marginal product schedule, separating them into distinct organizations would allow pay to be set more closely to market levels. Batt (2001) finds support for these claims in her study of wage inequality in the telecommunications industry. Specifically, she found that the breakup of the Bell system in 1984 allowed wage inequality among telecommunications service and sales workers to grow over 30 percent between 1983 and 1998. Though the "bust-up” takeover wave subsided by the end of the 1980s, restructuring 
persisted throughout the following two decades. Beginning in the early 1990s, the use of outsourcing helped disaggregate corporate employment further. When a large firm externalizes employment by outsourcing, the distribution of jobs within it changes as entire functions and departments are routinely extricated from within the firm's boundaries and handed to outside vendors. Cappelli (1999: 74) recounts how IBM outsourced all clerical jobs below the rank of executive secretary to employment agencies such as Manpower Inc. In so doing, these jobs became separated from the ILMs that reduced wage disjunctures within the firm. Dube and Kaplan (2010) found that outsourced janitors and security guards earned routinely less than their in-house counterparts, primarily by removing mid- to high-paying jobs and turning them into lower-paying jobs. By moving employees outside the boundary of the firm, outsourcing limits the amount of within-firm heterogeneity of abilities and rewards, reducing envy and social comparison costs (Rawley and Simcoe, 2010: 1535).

Though the dynamics mentioned above, in aggregate, shrank firm boundaries such that the average proportion of U.S. workers employed in the largest 100 firms declined during the observation period (Davis and Cobb, 2010), the trends varied across the U.S. states. Between 1978 and 2008, the proportion of the labor force employed by firms with at least 10,000 employees domestically declined in 17 states and increased in 31 states. We can thus exploit this variance to examine whether within-state changes in large-firm employment have affected changes in the rates of income inequality within those states over time.

\section{Wage Compression and State-level Income Inequality}

In the sections above, we assumed that individuals make social comparisons that create costs for their employers, that these costs are proportionately greater in larger firms than in smaller ones, and that managers are likely to compress wages to cope with social comparison 
costs. Though research has focused primarily on how comparison costs_-and the strategies that managers employ to mitigate them-affect organizational outcomes, we argue that these strategies also affect the distribution of income in a labor market. We do not suggest that all large firms compress wages or even that, within a given firm, all employees are subject to the same wage-setting considerations (Lepak and Snell, 1999). Nonetheless, because large firms on average are expected to compress wages to maintain perceptions of equity (Nickerson and Zenger, 2008), we expect to find, controlling for the size of the state's labor force, a negative relationship between large-firm employment and income inequality at the labor market level. [--- Insert Figure 1 about here ---]

To illustrate the mechanisms undergirding the aggregation process we describe above, consider the following example (see Figure 1). Let us take a hypothetical state where in year 1 all labor market participants work for a single employer that compresses wages to constrain the disjuncture between differentially skilled workers. In this firm, lower-skilled workers are paid, on average, above their marginal product while higher-skilled workers are paid closer to or below their marginal product. Income inequality in this case, as measured by the Gini coefficient, is $20.4 .^{2}$ In year 2, half of all workers remain employed by the large firm, and the other half are outsourced, work as independent contractors, and get paid according to their marginal product. The slope between wages and skill will be greater than in year 1, and the Gini

\footnotetext{
${ }^{2}$ In this example, skill levels range from 0 to 100 in increments of two. There is an equal number of individuals working at each skill level in each year. Individual wage rates vary depending on whether the individual is employed by the firm or is an independent contractor. The wage rates were calculated using the formulas below:

$W_{\text {large firm }}=\frac{\left(s+\left[\left(\frac{1}{2}\right) \times \ln (s)\right]\right)}{2} \times \$ 1,000$

$W_{\text {market }}=s \times \$ 1,000$

where $s$ equals the worker's skill level. The Gini coefficient was calculated for each state-year using the ginidesc command in Stata.
} 
coefficient increases to 25.8. In year 3, all labor force participants are independent contractors paid according to their marginal product. In year 3, the Gini coefficient increases to 32.7. As such, we suggest the following:

Hypothesis 1: As fewer (more) workers in a state are employed by large firms, income inequality in the state will increase (decrease).

While organizational membership serves as a powerful force in determining the referents used in social comparisons within organizations, additional factors may influence this process. In the sections below, we highlight two: racial diversity and establishment dispersion.

\section{Social Comparison and the Moderating Impact of Racial Diversity}

Prior research has established that social comparison processes are affected by the propensity of individuals to demarcate collectives into social categories (e.g., Blanton, Crocker, and Miller, 2000). Because demographic characteristics are commonly used to distinguish social categories (Tajfel, 1978) and shape the formation of identity groups (Alderfer, 1977), demographic diversity may create a larger number of social categories within the firm, thereby minimizing the scope of social comparisons. Employees who are demographically similar are more likely to view themselves as part of the same social category and select other category members as their referents when making social comparisons (Goodman, 1977). That is, whites are more likely to compare their opportunities and rewards to other whites, blacks to blacks, etc. People tend to make within-group comparisons because they assume in-group referents are similar in attributes related to achievement, such as education and background (Gibson and Lawrence, 2010). We should expect, then, that social comparisons will operate more strongly within these social categories than between them.

To compare differences between groups, individuals engage in social contrasting (Harris, Anseel, and Lievens, 2008). Although people often seek information about others who are 
dissimilar, social contrasting does not assume expectations of equal entitlement across social categories. Rather, social contrasting assumes that individuals will expect unequal treatment visa-vis individuals who are dissimilar (Lansberg, 1989). The unequal outcomes received by disadvantaged members are often then appraised as legitimate (Wood, 1994) or are otherwise discounted (Markovsky, 1985). Consequently, comparisons with dissimilar individuals do not invite the same sort of reactions as do comparisons with similar ones. More demographically homogenous firms should therefore have a smaller number of social categories, which would expand the number of salient referents within each category, placing greater pressure on organizations to employ strategies to minimize social comparison costs.

Yet studies have also shown that larger firms are more likely to standardize their wagesetting functions, which can help close the wage gap between the more-advantaged groups and the less-advantaged groups (Hirsh and Kornrich, 2008). This standardization implies that minorities working in large firms receive greater rewards than do otherwise similar minorities working in small firms, and also that there should be a narrower wage gap between otherwise similar white and minority workers in large firms. Within the United States, evidence reveals that racial wage gaps have remained relatively constant (see Leicht, 2008) or declined modestly over the past 40 years (Lang and Lehmann, 2012). Nevertheless, in our study large firms have become much more racially diverse during this period, suggesting that the increased diversity of largefirm employment has not closed racial wage gaps—at least in the aggregate.

Moreover, research has found that perceptions of fairness and egalitarianism are stronger in more demographically homogenous groups (Rothschild-Whitt, 1979) and that diverse groups have more dispersed wages than homogenous groups (Pfeffer and Davis-Blake, 1990). Carrington and Troske (1998) found in a study of large manufacturing firms that most of the 
black-white wage gap among men was accounted for by within-plant differences. Additionally, they found that whites earn more in plants with more blacks and blacks earn the most in plants that are nearly all white. In other words, while racial minorities may benefit from large-firm employment, that advantage occurs when the overall diversity of the firm is lower. Consistent with our argument that the need to compress wages horizontally and vertically is weaker when firms are more racially diverse, the wage gaps between minority and white workers will also be greater. Accordingly, we expect that social comparisons will operate less vigorously as large firms become more racially diverse, allowing managers to engage in less wage compression.

Hypothesis 2: The negative effect of large-firm employment on income inequality will weaken (strengthen) as employment in large firms in a state becomes more (less) racially diverse.

\section{Social Comparison and the Moderating Impact of Establishment Dispersion}

In addition to compressing wages, managers can reduce social comparison costs by increasing the physical and informational distance between jobs (Nickerson and Zenger, 2008: 1437). Prior work has established that distance serves as an important barrier to the diffusion and exchange of information (Sorenson, 2003), which could hinder the ability of workers to know about the rewards of less-proximate others. Distance will also hinder the formation of social ties (Festinger, Schachter, and Back, 1950), which are crucial to the formation of reference groups (Lawrence, 2006). Conversely, when workers are located in close proximity to one another, they are more likely to identify each other as salient referents, which can increase the costs of social comparisons if their income is more dispersed (Obloj and Zenger, 2015).

To proxy for the physical and informational distance between workers in a firm, we examine the extent to which large-firm employment is spread out across a larger number of establishments - that is, separate locations where the firm's business is conducted. As firms grow, they often build or acquire new plants and subsidiaries in different locations, which 
increases both the physical and informational distance between jobs. While geographic expansion may give firms access to new markets, lower costs, and other operational benefits, it can also lower social comparison costs as workers have a smaller set of salient referents with whom to compare. In fact, one reason firms may create separate establishments is to separate higher-wage workers from lower-wage ones, which reduces social comparison costs by putting greater physical and informational distance between workers (Nickerson and Zenger, 2008).

To illustrate, imagine a firm that employs two types of workers: highly skilled engineers and lower-skilled production workers. Were the firm to have all workers employed in the same location, giving a raise to the engineers would likely elicit envy among production workers. However, were production and engineering separated in different establishments, production workers might be less aware of wage increases for engineers. Thus, by segregating high and lowskill workers in separate establishments, the firm may be better able adjust wages for engineers without having to increase wages for production workers (see Obloj and Zenger, 2015).

There may be reasons to expect, however, that this relationship might not be so straightforward. If, for example, large firms standardize wages as a means to economize on monitoring, information, and/or administrative costs, we might expect that the firms' wage distributions will be unaffected by establishment dispersion. Furthermore, employees may still have information on wage differentials across establishments. Williamson (1985) recounts the story of a failed post-merger integration between Tenneco Inc. and Houston Oil and Minerals Corp. because of the variance in how workers from the old and new firms were paid, suggesting that maintaining wage-setting consistency across establishments is still necessary to minimize social comparison costs. Despite these possibilities, if establishing new plants and subsidiaries allows firm managers to have more discretion in differentiating rewards across workers or to 
segregate higher- and lower-income workers, managers of these firms will have less need to compress wages. Hence, we expect that when large firms' employment is spread out over a larger number of establishments, overall social comparison costs should be lower and firms will have less need to compress wages. Stated formally, we expect the following:

Hypothesis 3: The negative effect of large-firm employment on income inequality will weaken (strengthen) as employment in large firms in a state becomes more (less) dispersed across establishments.

\section{DATA AND METHODS}

\section{Unit of Analysis and Sample}

A critical component of examining the connection between organizational demography and rising income inequality at the state level is establishment-level employment data derived from reports filed annually with the Equal Employment Opportunity Commission (EEOC), known as EEO-1 reports. ${ }^{3}$ As mandated by Title VII of the Civil Rights Act (1964), the EEOC requires all private work establishments with at least 100 employees, all federal contractors with at least 50 employees, and first-tier subcontractors in agreements worth at least $\$ 50,000$ to file these reports each year. EEO-1 reports cover approximately 40 percent of private-sector employment nationally (Robinson et al., 2005) and contain information on an establishment's size, parent company, industry, demographic composition (e.g., race/ethnicity, sex), and employment across nine occupational categories: officials and managers; professionals, technicians, sales workers, administrative support workers, craft workers, operatives, laborers and helpers, and service workers. Because the data are at the establishment level (i.e., individual work sites) rather than firms as a whole, we were able to isolate firm employment at the state level. The EEOC data are coupled with data from a variety of sources, including the Bureau of

\footnotetext{
${ }^{3}$ The EEO-1 reports are confidential and not publicly available; the data were obtained from the EEOC through an Intergovernmental Personnel Act (IPA) agreement by one of the authors.
} 
Labor Statistics, Bureau of Economic Analysis, and U.S. Census Bureau, among others. Table 1 contains information on the data sources for each of the variables used in the study.

$$
\text { [--- Insert Table } 1 \text { about here ---] }
$$

While we cannot directly assess wage compression or the presence of corporate restructuring, we can capture shifts in the number of workers in a state employed by large firms as well as the racial diversity and establishment dispersion of large firms, allowing us to determine whether these organizational factors have influenced changes in income inequality over time. The sample includes all U.S. states for which we could find reliable measures for income inequality, corporate employment, racial diversity, establishment dispersion, and the control variables between 1978 and 2008. Because of missing data on some of the covariates, the final balanced sample consists of 1,488 observations from the 48 contiguous states. ${ }^{4}$

We chose to analyze states because there are far better data for states than for any other sub-national entity. Annual historical data on income inequality and other covariates are not available below the state level, complicating efforts to examine factors related to income inequality at lower levels of analysis. Furthermore, while conventional wisdom suggests that workers are more mobile now than in years past, evidence finds that interstate migration is low and has been falling since the early 1980s (Molloy, Smith, and Wozniak, 2013), suggesting that states are a suitable labor market for the study of firms and income inequality.

\section{Measures}

Dependent variable. The measure of income inequality used in this study is the Gini coefficient, which measures the extent to which the distribution of income deviates from a

\footnotetext{
${ }^{4}$ Data on educational attainment was not available for Alaska or Hawaii, and there appear to be issues with missing employment data for both of these states prior to 1986. Inclusion of both states without the measures of educational attainment from 1986 to 2008 does not materially affect the results.
} 
perfectly equal distribution. The Lorenz curve is a graphical representation of cumulative income share on the vertical axis and the distribution of the population on the horizontal axis. Specifically, each point on the Lorenz curve represents the share of income held by $x$-percent of the population. The Gini coefficient measures the percentage of area that lies between the Lorenz curve and a line of perfect equality. The coefficient varies between 0 , which represents complete equality, and 1, which indicates complete inequality (i.e., one person earns all income). For ease of interpretation, we express the Gini coefficient in percentage terms.

The historical Gini coefficient data were compiled from pre-tax income from IRS tax records by Frank (2009). At the national level, capital income (e.g., capital gains and dividends) are separated from salary income; however, at the state level, there is no way to distinguish between the two sources. Atkinson et al. (2011) find that, for top earners in the United States since 1970, income is derived primarily from salary, suggesting that any concerns regarding whether our measure of income inequality is affected by capital income are minimal. To ensure that our results were not sensitive to the ultimate source of the data, we also used Gini data taken from the Current Population Survey (CPS), available through the University of Texas Inequality Project (Galbraith and Hale, 2008). The results are consistent with those presented here.

Independent variables. Our main independent variable is large-firm employment. Corporate employment data at the state level were derived from EEO-1 reports, as described above. One challenge in capturing employment by a state's largest employers is that there is no consensus about what constitutes a "large" firm. Prior studies have used 1,000 employees, which is the largest category used in many individual-level datasets such as that of the CPS, as the cutoff (e.g., Bidwell, 2013). The U.S. Census Bureau, however, provides aggregated employment data at the national level for firm sizes up to 10,000 employees. In the analyses 
presented below, we used as our measure of large-firm employment the log value of the number of workers in each state employed by firms with 10,000 or more workers nationally. ${ }^{5}$ Thus, if a firm has 10,000 domestic workers, where 5,000 worked in State A and 5,000 worked in State B, our measure of large-firm employment in each state would reflect the 5,000 workers employed in each state. The correlation between the log number of workers in a state employed by firms with $1,000,5,000,10,000,20,000$, and 50,000 or more workers all exceed .97 . We ran analyses using these cutoffs, and the results are largely consistent with those presented below.

Our examination of racial diversity's effect on the relationship between large-firm employment and income inequality is based on the conceptualization of diversity as "variety" (Harrison and Klein, 2007), with specific interest in the distribution of employees across distinct racial categories within firms. These racial categories do not possess meaningful continuous distances between them and, as such, we created a Blau index of racial diversity for each firm from EEO-1 reports to capture the spread of individuals across qualitatively distinct racial categories. The Blau index reflects the chance that two randomly selected group members belong to different categories. Its computational formula is $1-\Sigma p_{k}{ }^{2}$, where $p$ is the proportion of unit members in the $k$ th category. We then standardized the Blau index by dividing it by its theoretical maximum, $(K-1) / K$, where $K$ represents the total number of categories, to create the index of quality variation (IQV) of racial diversity for each large firm. We have four race categories—white, black, Hispanic, and Asian—so the theoretical maximum for racial diversity

\footnotetext{
${ }^{5}$ Davis and Cobb (2010) used the ratio of employees working in the largest firms over the size of the labor force as their measure of large-firm employment. Following this approach would allow us to capture the hypothesized dynamics in a single, self-contained measure. Yet, prior research has argued that using ratios in regression analyses may lead to spurious findings since the correlations among ratios will produce a non-zero association even though the components (i.e., the numerators and denominators) are unrelated (Wiseman, 2009). In the supplemental analyses we test our hypotheses using the ratio measure of large-firm employment.
} 
is $.75 .{ }^{6}$ We took a weighted average of the IQV index of racial diversity for all the large firms that employed workers in each state in each year and multiplied this value by 100 for ease of interpretation to derive our measure of large-firm racial diversity. In 1978, the average racial diversity of large firms was 36.53 (s.d. 5.05). By 2008, that number was 65.35 (s.d. 5.30). In supplementary analyses, we examine alternative measures of racial diversity.

The EEO-1 reports contain employment data for each establishment, allowing us to calculate how dispersed each firm's employment was across establishments. To examine the effect of large-firm establishment dispersion on the relationship between large-firm employment and income inequality, we created a Blau index to indicate how dispersed employment was in each large firm. ${ }^{7}$ We took a weighted average of the Blau index for all the large firms that employed workers in each state in each year, giving us a state-level index of establishment dispersion. Once again, we multiplied the measure by 100. In 1978, the average establishment dispersion of large firms was 94.37 (s.d. 2.37). By 2008, that number was 97.56 (s.d. 3.19). In the supplemental analyses, we examined an alternative measure of establishment dispersion.

Control variables. Income inequality may relate to several factors not included in the discussion of the hypotheses. It is possible that large-firm employment, diversity, and establishment dispersion are due, in part, to the size of a state’s labor force and economy. To account for these possibilities, we include a log measure of each state's nonfarm labor force and the natural log of the state's real gross domestic product per capita (GDP per capita).

\footnotetext{
${ }^{6}$ Because whites and Asians tend to be advantaged in the labor market in comparison to blacks and Hispanics, we also calculated an IQV measure of inequality using two categories: (a) white and Asian, (b) black and Hispanic. The results are similar to those presented below.

${ }^{7}$ Because there is no theoretical maximum for the number of establishments a firm can have, we do not standardize our measure of establishment dispersion. For robustness, we did, however, assume a theoretical maximum equal to the largest number of establishments we observe in our sample and standardized our measure of establishment diversity with this number. The results are nearly identical to those presented below.
} 
Because we are interested in how racial diversity affects the relationship between largefirm employment and income inequality, we include a measure of the percentage of each state's labor force that is black (black employment). We tested alternative measures, such as the percentage that is black and Hispanic and the percentage that is nonwhite, and the results are similar to those presented below. The BLS, in its "Geographic Profile of Employment and Unemployment," presents collected data that break down each state’s labor force by race for 1970, 1980, 1990, and annually from 1999 onward. Thus, we linearly interpolated the BLS data for the intervening years and found that this measure and our EEO-based measure were correlated at .98. The results are unaffected by the data source. Because research has shown that there are differences in worker skill and returns to worker skill in urban versus non-urban settings (Bacolod, Blum, and Strange, 2009), we controlled for the proportion of each state's population that lives in urban areas (urban population). We linearly interpolated these data for the relevant years between 1970, 1980, 1990, 2000, and 2010.

It is possible that racial diversity and establishment dispersion are affected by changes in the types of occupations large firms now employ. To account for these shifts, we created variables to represent the average proportion of large-firm employment in a state in production, professional, and service occupations. Following Lin (2013), we divided the total number of workers in each occupation by the total number of workers employed by large firms for each state in each year. Production employment includes technicians, craft workers, operatives, and laborers and helpers. Professional employment includes managers and professionals. Service employment includes sales workers, administrative support workers, and service workers. Because the three measures are highly correlated with one another, we include only the largefirm service employment measure in our analyses. We also analyzed production and professional 
employment in separate equations and the results were similar to those presented below.

To rule out the possibility that our measures of large-firm employment, racial diversity, and establishment dispersion simply capture the propensity of workers to be employed in certain industries that vary in their pay practices, we included several state-level control variables related to industry employment. Because there are a limited number of within-state observations, we faced some constraints regarding the number of industry employment variables that we could include in our analyses. To determine which measures to include, we regressed the percentage of employment in the agricultural, manufacturing, construction, mining, retail, FIRE (finance, insurance, and real estate), government, and temporary employment sectors along with year dummies on state levels of income inequality and found that manufacturing and government employment had a significant and negative relationship; retail had a significant and positive relationship; and agricultural, construction, mining, FIRE, and temporary employment had no relationship with income inequality. Based on these results, we included measures of government employment, manufacturing employment, and retail employment. ${ }^{8}$

The relative skill of workers in a state, which some scholars have argued is a direct cause of rising income inequality (e.g., Autor, Levy, and Murnane, 2003), may also influence largefirm employment, diversity, and establishment dispersion. While we do not have data on the individual characteristics of employees, a common proxy for worker skill is the level of worker education in a population (Alderson and Nielsen, 2002). We included a measure of the percentage of individuals in the state who are college graduates (percentage college graduates). To account for the influence of globalization, we include a measure of the logged real foreign direct investment. Rates of income inequality as well as large-firm employment, diversity, and

\footnotetext{
${ }^{8}$ As a robustness check, we also ran models including agricultural, construction, mining, FIRE, and temporary employment, and the predicted findings are unaffected by their inclusion.
} 
establishment dispersion may also be influenced by rates of unionization, which have been found to be negatively related to income inequality (Western and Rosenfeld, 2011). Therefore, we include a control for union density. Additionally, we included a measure of the state's rate of unemployment to account for broader labor market conditions that may affect the relationship between large-firm employment and income inequality.

We also included measures to capture the impact of public policy on income inequality. A number of researchers have suggested that the political ideology in a region has important implications for levels of income inequality (e.g., Volscho and Kelly, 2012). To account for the extent of a state's liberality, we take an equally weighted average of the percentage of Democrats in each state’s House of Representatives and Senate for each year of study (Democrats in state legislature). To test the influence of a specific policy designed to redistribute income more directly, we include a measure of the state income tax rate. The rate is the maximum rate for an additional $\$ 1,000$ of income on an initial $\$ 1,500,000$ of wage income split evenly between husband and wife filing a joint tax return and includes combined state and federal income taxes.

Studies have also found minimum wage rates to be an important predictor of income inequality. To calculate the real minimum wage, we took the greater value between federal and state minimum wage rates. ${ }^{9}$ In cases where the effective date of change was in the middle of the year, we took a weighted average of the minimum wage pre- and post-change. We then deflated this by the consumer price index $(1982$ - $1984=100)$. To capture the extent of redistribution policy at the state level, we included a measure of the real real government transfers per capita.

\footnotetext{
${ }^{9}$ Some researchers have argued that, because federal minimum wage rates do not apply to all workers, one should examine state minimum wage rates even if they are below the federal rate (e.g., Volscho, 2005). While true, a significant percentage of workers are covered by federal wage laws, and where workers are covered by both state and federal law, the higher rate applies. Because there are 230 state-years where the state had no minimum wage and 531 state-years where the state minimum was lower than the federal rate, using the state rather than the higher of the federal or state rate may overstate the impact of state rates on income inequality.
} 
We included only total state-level receipts of retirement, income maintenance, and state and federal unemployment benefits rather than cash-in-kind benefits such as medical and food assistance. The results are similar if we use all benefits. We divided transfers by the population of the state and took the natural log of this figure.

Aghion and colleagues (2015) recently used state-level panel data to investigate the cooccurrence of rising rates of innovativeness and income inequality. While their study included several measures of income inequality, a positive and significant relationship was found between innovation and the top 1-percent income share, specifically, and not the top 10-percent income share or other measures that capture the entire distribution of incomes (e.g., the Gini coefficient). Despite there only being a significant relationship between innovation-led growth and top incomes in their study, we included a control for state-level innovation, as it may affect the relationship between large-firm employment and income inequality. Innovation is captured by the number of patents granted by the U.S. Patent and Trademark Office per 1,000 people.

We also include year dummy codes in all of our analyses, which allows us to attribute some of the variation in our data to unobserved events in a given year, such as events that affected overall changes in income inequality and the other covariates. ${ }^{10}$ The correlation matrix is presented in Table 2. We checked for possible multicollinearity in our model by conducting a variance inflation factor (VIF) test. The maximum VIF score obtained for our independent variables was 1.97 and the overall mean VIF was 2.72, both below the commonly used threshold value of 10 (Kennedy, 2003), indicating that multicollinearity was not a concern.

[--- Insert Table 2 about here ---]

\footnotetext{
${ }^{10}$ Because we expect that our key independent measures should have a contemporaneous effect on individual income and thus income inequality at the state level, we do not include lagged measures of our measures in our main analyses. For robustness, we ran analyses using lagged measures of the covariates to predict state rates of income inequality. The results are similar to those presented below and are available upon request.
} 


\section{Analytic Approach}

In this study, the unit of analysis is the state, and the unit of observation is the state-year. Our dependent variable is income inequality, which we measure using the Gini coefficient. To examine the relationship between income inequality and large-firm employment, racial diversity, and establishment dispersion, we use a fixed effects, pooled time-series regression analysis. This specification is achieved by subtracting the values of each observation from the state mean, removing all between-firm differences, and leaving only within-state variation to be explained by the covariates (Wooldridge, 2002). A fixed effects framework helps rule out the possibility that states had stable unobserved factors that influenced income inequality. Specifically, we estimate the effects of the covariates on the Gini coefficient as follows:

$$
Y_{i j}=\beta_{0}+\beta_{1} X_{1 i j}+\beta_{2} X_{2 i j}+\beta_{3}\left(X_{1 i j} \times X_{2 i j}\right) \ldots+\beta_{p} X_{p i j}+\alpha_{j}+\varepsilon_{i j}
$$

where all state-specific effects are accommodated by $\alpha_{\boldsymbol{j}}$, the error term is captured by $\boldsymbol{\varepsilon}_{\boldsymbol{i} \boldsymbol{j}}$, and within-state effects are explained by the covariates, represented by the $X$ s.. Some scholars question the use of fixed effects in cross-national studies of income inequality, noting that much of the variance occurs between countries (Alderson and Nielsen, 2002). Prior work, however, suggests that these concerns are minimal when analyzing states (Frank, 2009).

\section{RESULTS}

The results of the fixed effects regressions are listed in Table 3. Model 1 contains the results of the controls. In model 2, we introduced our measure of large-firm employment. We included the main effect measures of racial diversity and establishment dispersion in model 3. In models 4 and 5, we tested the interactions between large-firm employment and racial diversity and large-firm employment and establishment dispersion, respectively.

$$
\text { [--- Insert Table } 3 \text { about here ---] }
$$


It is worth noting that a number of control variables are significantly related to changes in state income inequality. The size of the labor force is positively related to income inequality, as is foreign direct investment. Conversely, the proportion of workers employed in manufacturing industries, the real minimum wage, and the percentage of Democrats in the state legislature are negatively related to income inequality. Furthermore, we also see a positive and significant relationship between the main effect of large-firm racial diversity and income inequality. Though we did not hypothesize this main effect, the results were unexpected as they indicate that income inequality in a state increases as the racial diversity of large firms in a state increases. We discuss this finding further in the Discussion section.

For hypothesis 1, we predicted that large-firm employment would be negatively related to income inequality. The results indicate that income inequality is lower when a larger number of workers within a state are employed by large firms, offering support for the first hypothesis. Based on the results in model 3, a 10 percent increase (decrease) in non-log transformed largefirm employment lowers (raises) the Gini value by 0.29 points ( 0.51 percent). Though appearing somewhat small, the size of the effect of large-firm employment on income inequality is net of controls and state- and year-fixed effects. Furthermore, Volscho (2005) found that a $\$ 0.81$ increase in the real hourly minimum wage rate would decrease the Gini coefficient 0.10 points for the average state, suggesting that large-firm employment has a similar effect on state levels of income inequality as a $\$ 2.40$ increase in the real minimum wage. In the supplemental analyses, we further discuss the magnitude of the hypothesized effects on changes in income inequality.

Hypothesis 2 predicted that a greater extent of racial diversity in large employers in a state will moderate the relationship between large-firm employment and income inequality such that the effect becomes weaker. In support of hypothesis 2 , the results in model 4 reveal a 
positive and significant relationship between income inequality and the interaction of large-firm employment and diversity. For hypothesis 3, we predicted that when large-firm employment is more dispersed across establishments, the negative relationship between large-firm employment and income inequality will become weaker. The coefficient for the interaction term is significant and positive, which supports hypothesis 3 .

To gain more insight into the interaction effects, we plotted the significant interactions based on models 4 and 5 in Figure 2. ${ }^{11}$ We also followed Aiken and West’s (1991) procedure and conducted simple slope tests for significant interactive terms. We split the large-firm employment variable into two groups—-low (one standard deviation below the mean) and high (one standard deviation above the mean)—and estimated the effect of racial diversity and establishment dispersion for both levels. We find that racial diversity is negatively related to income inequality when large-firm employment is high (simple slope $b=0.199, p<0.05$ ), but not when it is low $(b=0.104, p>0.10)$, supporting hypothesis 2 . Employment dispersion is not significantly related to income inequality when large-firm employment is high $(b=-0.006, p>$ $0.10)$ or low $(b=-0.008, p>0.10)$. Given that Figure 2 indicates the presence of a modest crossover interaction, this null result is not surprising (Keppell and Wickens, 2004). However, because the results of model 5 do not fully conform to our theory and because we did not find a consistent effect of this interaction term in our supplementary analyses (see below), we do not find strong support for hypothesis 3.

[--- Insert Figure 2 about here ---]

Interpretation of results. In order to better illustrate the magnitude of our effects as well

\footnotetext{
${ }^{11}$ We centered our main independent variables prior to creating the interaction terms, which were used in creating this plot. For ease of interpretation, we changed the labels of the $\mathrm{x}$-axis of Figure 2 to the corresponding uncentered values of large-firm employment.
} 
as examine some of the state-level variation in income inequality and large-firm employment, we ran a set of models using the ratio of the number of workers employed by large employers to the size of the overall nonfarm labor force as our measure of large-firm employment (see Davis and Cobb, 2010). This choice was motivated by the fact that the log value of large-firm employment increased or held relatively constant in most states during the observation period. Yet in many of these states, the size of the labor force grew such that the proportion of workers employed by large firms declined. For the purpose of illustrating our results, using the proportion of workers employed by large firms gives us more flexibility as it allows us to hold constant all the other covariates while manipulating a single, scaled measure of large-firm employment. The results of the analyses, which can be found in Table 4, reveal a negative and significant relationship between the ratio measure of large-firm employment and income inequality; however, this relationship is weaker when those those large employers are more racially diverse.

Figure 3 shows the changes in the Gini coefficient between 1978 and 2008 on a map of the contiguous 48 U.S. states. As we mentioned above, income inequality increased in each state during the observation period; however, the rate of increase varied widely. The numerical values reflect the changes in the percentage of the nonfarm labor force in each state that worked for large firms during the period and reveal that states also varied in the extent to which their labor force remained employed in large firms. Several states throughout the Northeast and Midwest regions, including New York, Vermont, Indiana, Michigan, and Ohio had proportionally fewer workers employed in large firms over the study period. Conversely, throughout the Central and Southeast regions, states such as Kansas, Nebraska, Colorado, Arkansas, and Florida had proportionally more workers employed in large firms. While there are exceptions, states in which there was a decline in the proportion of workers in the labor force employed tended to have 
greater increases in income inequality, while those where the proportion of workers employed by large firms increased had smaller increases in income inequality.

$$
\text { [--- Insert Table } 4 \text { about here ---] }
$$

We also conducted a series of counter-factual analysis on two states, Michigan and Virginia, to see how income inequality in 2008 would have varied had the proportion of workers employed by large firms in each state remained at its 1978 level. In other words, we ask what the level of inequality would be in each state if there had been no change in the ratio of workers employed by large firms. We chose these two states because they have roughly similar labor force sizes in labor force size and experienced roughly similar changes in the ratio of the labor force employed by large firms. However, in Michigan, the proportion of workers employed by large firms declined, whereas in Virginia, the proportion of workers employed by large firms increased. Had the proportion of workers employed by large firms remained at 1978 levels in Michigan, the predicted Gini coefficient would have been 2.27 points (3.4 percent) lower. In Virginia, the predicted Gini coefficient would have been 1.66 points (2.3 percent) higher. To put these counter-factual results in some perspective, using the results from model 6, the reduction in income inequality for Michigan associated with maintaining the same proportion of large-firm employment over the period would be equivalent to the effect of a hypothetical increase in the miminum wage in 2008 from $\$ 7.28$, to $\$ 11.70 / \mathrm{hr}$ in that state. ${ }^{12}$ For Virginia, maintaining the same proportion of large-firm employment over the period would be equivalent to the effect of a hypothetical decrease in the minimum wage in 2008 from $\$ 6.16$, to $\$ 3.88 / \mathrm{hr}$ in that state. ${ }^{13}$

\footnotetext{
12 The minimum wage rate in Michigan increased from \$7.15/hr to \$7.40/hr effective July 1, 2008.

13 The minimum wage rate in Virginia increased from \$5.85/hr to \$6.55/hr effective July 24, 2008.
} 


\section{Supplementary Analyses}

In this section, we present various robustness checks and extensions of our baseline analysis. Unless noted, the full complement of control variables was included in the models.

Distributional effects. Using aggregate measures of income inequality may mask where in the income distribution the covariates have the strongest effect, as the Gini coefficient can increase for different reasons, such as when top incomes increase and/or low incomes decrease. We predicted that large-firm employment affects income inequality by raising the wage floor for lower-skilled workers relative to higher-skilled ones; therefore, large-firm employment should have a positive and significant effect on incomes at the lower end of the income distribution while having no effect, or possibly a negative effect, on incomes at the higher end of the income distribution. To test this assumption, we used data taken from http://www.inequality.org/ and ran fixed effects regressions where the dependent variable is the total annual wage and salary income at each decile. The results of the analyses for the 10th, 30th, 50th, 70th, and 90th deciles can be found in Table 5, models 8 through 17. As Table 5 indicates, large-firm employment has a positive and significant effect on incomes at the 30th, 50th, and 70th percentiles. However, it has no effect on incomes at the 10th or 90th percentiles. Large-firm employment also has a positive and significant effect on incomes at the 20th, 40th, and 60th percentiles but no effect on incomes at the 80th percentile. These findings indicate that large-firm employment increases incomes for individuals at the lower, middle, and upper-middle portions of the income distribution. These results suggest that state levels of income inequality are lower, in part, because large-firm employment raises wages for these individuals. We also see that this positive effect is negatively moderated by the racial diversity of these large firms, which is consistent with hypothesis 2 .

[--- Insert Table 5 about here ---] 
Additional analyses. In observational studies of this type, establishing causality between the covariates and the dependent variable can be challenging, and we are aware of concerns about endogeneity affecting the associations along with any inferences made about causality. We attempted to address this concern empirically using Arellano-Bond estimator models. We also tested several different measures of income inequality, racial diversity, and establishment dispersion. The results of these tests, which can be found in the online supplement, are largely consistent with those in Table 4. Specifically, we find a significant and negative relationship between large-firm employment and income inequality, though this effect is weaker when the state’s large firms are more racially diverse. We see no effect for establishment dispersion. Taken together, the results of our analyses provide some confidence that, regardless of how the constructs are measured and analyzed, when a state's employment is more heavily concentrated within large employers, income inequality is lower. When those workforces are more racially diverse, the relationship between large-firm employment and income inequality becomes weaker.

\section{DISCUSSION}

Over the past 40 years, there has been a general trend of rising levels of income inequality in the United States. While prior research has offered important insights into the role played by human capital characteristics, market forces, and institutional changes for this rise, less attention has been afforded to the study of how firms affect income inequality in the broader labor market. We complement and extend this emerging work by advancing a uniquely organizational account of rising income inequality within U.S. states over time. Specifically, we propose that the propensity for workers in a state to be employed by large firms is negatively related to income inequality at the state level. Drawing upon research on social comparisons, we argue that large firms are particularly susceptible to invidious social comparisons and undertake 
strategies to help ameliorate their damaging effects. By compressing wages, large firms pay some workers, typically lower-wage workers, more than their market wage and other workers, typically higher-wage workers, less than the market wage. In so doing, these strategies affect the distribution of wages throughout the labor market. The results support our argument, as largefirm employment has a significant and negative relationship with income inequality.

We also argued that social comparison processes will operate less vigorously when large firms are more racially diverse, thus allowing these firms to compress wages to a lesser extent. The results showed that the relationship between employment in a state's largest firms and income inequality becomes weaker when those large employers are also racially diverse. Importantly, we are not proposing that racial diversity is problematic. Rather, we are suggesting that, because of social categorization, social comparison processes operate differently in more diverse firms and that inequities between otherwise similar workers do not invite the same kind of invidious social comparisons. While there are many organizational and societal benefits to having a more diverse workforce, the results are consistent with the notion that, when large firms are more racially diverse, there is less pressure to compress wages, weakening the effect of largefirm employment on state levels of income inequality.

Similarly, we contended that social comparison processes will operate less vigorously when employment in large firms is more dispersed across establishments. Across models, however, we found little evidence to support our claims. Descriptive statistics revealed that there is little variance over time within states in levels of establishment dispersion, suggesting that employment in large firms is no more dispersed across establishments in 2008 than in 1978. Additionally, it is possible that large firms are prone to standardize wages across establishments.

Implications for organizational studies. Despite evidence suggesting that employers 
play a role in determining societal rates of income inequality, contemporary organizational scholarship has been mostly silent about the phenomenon. Scholars have explored the consequences of wage dispersion at the intra-organizational level (see Shaw, 2014) without much attention being given to where inequality emerges. Furthermore, organizational scholars have documented the practices used over the past four decades to reshape firm boundaries. Major organizational restructuring resulted from leveraged buy-outs, mergers and acquisitions, divestitures of unrelated businesses, and the growth of contract and temporary work (Davis and Stout, 1992; Cappelli and Keller, 2013; Feldman, 2014). Despite these radical changes to firm boundaries and organizational practices over the past 40 years, few attempts have been made to link changes in corporate demography to broader labor market outcomes.

We see these oversights as part of a broader trend whereby the impact of firms on society is largely ignored in contemporary scholarship on organizations (Tilcsik and Marquis, 2013; Cobb, Wry, and Zhao, 2016). How organizations affect the general social welfare was a key focus of earlier scholars (e.g., Whyte, 1956), and the neostructuralist perspective of stratification was keenly interested in the impact of hierarchies on inequality, arguing that firms, through their decisions regarding their job allocation and wage-setting, help determine levels of income stratification (Baron and Bielby, 1980). Empirical studies in this area, however, document the features of organizations associated with inequality within the firm (e.g., Pfeffer and Langton, 1988). In this study, we developed a simple theory that articulates a set of transformational mechanisms (Hedström and Swedberg, 1998) through which firm strategy and structure lead to state levels of income inequality. In so doing, we offer suggestive evidence that many of the changes to large corporate employers documented in other studies (Osterman, 1996; Davis, 2009a; Cobb, 2015) have played a role in rising levels of income inequality within U.S. states. 
Furthermore, by situating organizations squarely in the conversation on income inequality in the broader labor market, our approach highlights the nuanced relationship between firms and their increasingly diverse workforces. The practical inevitability of a racially diverse workplace has directed the attention of organizational scholars and practitioners alike toward understanding its challenges and opportunities (see Williams and O'Reilly, 1998), resulting in a considerable body of literature demonstrating how internal workplace conditions affect ascriptive inequality within organizations (e.g., Kalev, Dobbin, and Kelly, 2006). While internal organizational processes and dynamics are clearly important for our understanding of inequality, there are obvious implications beyond the boundaries of the firm. For example, Cohen and Huffman (Huffman and Cohen, 2004; Cohen and Huffman, 2007) suggest that black-white income inequality is driven by the underrepresentation of black employees in managerial positions relative to their concentration in the local labor market. Our research similarly moves beyond firm boundaries by exploring the interplay between corporate employment and the diversity of the workforce in affecting levels of income inequality in the broader labor market.

Implications for income inequality research. Existing perspectives on the rise of income inequality focus primarily on market-based (e.g., SBTC, globalization) or institutionalbased (e.g., unions, minimum wage) explanations (Morris and Western, 1999: 642). While each of these streams has provided valuable insights into the drivers of income inequality, considerable variance remains unexplained. As such, new and complementary explanations have the potential to add to our understanding of the phenomenon. In this study, we advance a firmcentered perspective on income inequality, arguing that, because employers help determine labor market outcomes (Baron and Bielby, 1980) and because much of the increase in income inequality is due to employers paying similar workers differently (Groshen, 1991), corporate 
organizations are an overlooked driver of income inequality at the state level.

We draw upon recent literature on social comparisons and firm boundaries (e.g., Nickerson and Zenger, 2008), the firm-size wage effect (e.g., Hollister, 2004), and the literature on organizational wage-setting (e.g., Granovetter, 1981) to elaborate a firm-centered theory for how income inequality within a labor market is influenced by the characteristics of employers in that market. A few scholars have been interested in how organizations affect income inequality and have focused on the important role played by corporate demography. We complement and extend the work of Davis and Cobb (2010) through data improvements and a clearer articulation of the theoretical mechanisms linking firm structure to income inequality. We also build on the work of Sørensen and Sorenson (2007) by focusing on the role of firm size rather than industrial diversity in influencing income inequality in a labor market.

Moreover, while the "state" is often treated as a single entity, a more realistic conceptualization is that of a highly differentiated and often loosely coupled political and economic entity operating across federal, state/region, and local geographies (Scott and Davis, 2007: 266). Previous studies have found relationships between income inequality at the U.S. state level and various factors such as the percentage of blacks in the labor force (e.g., Jonish and Kau, 1973), rates of immigration (e.g., Partridge, Rickman, and Levernier, 1996), political party influence (e.g., Kelly and Witko, 2012), and different public policies (e.g., Barrilleaux and Davis, 2003; Volscho, 2005). A related stream of research has also found that discrimination and attainment varies across the United States because of the legal institutions that are present in the state or community (e.g., Tilcsik, 2011). We add to this literature by documenting a relationship between the employment in large firms and income inequality at the state level. In so doing, our research also points to the importance and value of examining within-country patterns of 
inequality as well as the variance of corporate demography across labor markets.

Limitations and future directions. One limitation of this study is that we cannot examine the wage-setting practices of these large firms. Unfortunately, U.S. matched employeremployee data on a scale of this size do not readily exist, making it necessary to rely on the demographic dimensions of organizational populations (Carroll and Hannan, 2000). Future work can leverage matched employer-employee data available in many countries, such as Germany and throughout Scandinavia, to add increased precision to the mechanisms we propose here.

A related limitation is that we cannot capture social comparison dynamics directly and are instead relying on firm size as a proxy. We essentially argue that if existing theory about social comparison and firm size is correct, then the steps that firms take to manage social comparison costs have implications for income inequality in a labor market. As we mentioned above, there may be a number of reasons why a firm might compress wages. While the results of our moderators help provide some confidence that social comparisons are an important factor motivating firms to do so, we cannot rule out these alternative explanations.

The significant and positive main effect between the racial diversity of large firms and income inequality is an interesting finding and one potentially worthy of additional inquiry. In particular, one might reasonably expect that the wage standardization practices employed by large firms would have lowered overall income inequality by closing the racial wage gap. During the observation period, large-firm employment in most states became significantly more diverse. Evidence indicates, however, that the average racial wage gap in the U.S. remained relatively constant or declined modestly during the observation period (Leicht, 2008; Lang and Lehmann, 2012). Moreover, prior research has found that blacks earn more in establishments with a greater proportion of white workers (Carrington and Troske, 1998), casting some doubt on the idea that 
the increased racial diversity of large-firm employment should lower racial wage inequality. Future research can productively examine how changes in the racial diversity of organizations affect the distribution of income inside of firms as well as in the broader labor market.

Furthermore, we used establishment dispersion as a proxy for the physical and informational distance between jobs. Future work may be able to find more precise measures, such as geographic distance, to examine whether the proximity of workers across establishments moderates the relationships we hypothesized in the current paper. There are also other potential moderators between large-firm employment and income inequality, such as unionization and corporate governance structures, which may be of interest to future researchers as well.

Additionally, our theory also builds on the idea that, in large firms, lower-skilled workers receive a wage premium, whereas higher-skilled workers receive wages closer to or even below the going market wage. Yet we do not believe that these same dynamics apply well to wagesetting closer to the apex of the organization, as in the case of executive compensation. In recent years, a number of studies have found that when setting executive pay, corporate boards reference the pay of executives of similar firms and/or a set of "aspirational” firms that are typically larger and where executives get paid more (DiPrete, Eirich, and Pittinsky, 2010; Kim, Kogut, and Yang, 2015). Arguably, social comparisons still play a role in the setting of executive compensation; however, it is a comparison across firms rather than within them. As such, and as our supplementary analyses reveal, our theory is less applicable to measures that rely heavily on top incomes (e.g., the top 1 percent) and are more useful in explorations of income inequality that encompass lower income ranges (e.g., the Gini coefficient).

Finally, it is also important to recognize that the mechanisms that we address here are potentially unique to a given time and place and may not hold in other contexts. Over the past 
several decades, the U.S. economy has undergone a significant transition where measures of firm size such as revenues, assets, and employment have become increasingly disaggregated (Davis, 2009b). The largest employers are now concentrated more heavily in retail, whereas in the earlier half of our study period many large firms were still in industrial sectors (Davis and Cobb, 2010). Evidence also indicates a weakening of the FSWE (Hollister, 2004) and an increase in the use of pay-for-performance schemes to remunerate higher-skilled workers (Lemieux, MacLeod, and Parent, 2009), which would put their pay closer to market rates. As such, the connections we suggest here may have been stronger in earlier periods and may weaken or reverse as the economy continues to evolve and large firms use wage compression less frequently.

\section{CONCLUSION}

Over the past 40 years, large corporations in the United States have changed in dramatic fashion. Takeovers, divestitures, layoffs, outsourcing, and offshoring have all transformed firm boundaries. One result of this transformation is its effect on individuals, as the impact of many of these restructurings are borne disproportionately by the labor force. In this study, we argue and provide evidence that these changes in corporate organizations, which are not uniform across U.S. states, can partly explain increased income inequality at the state level. Large-firm employment and racial diversity are not the only factors affecting a state's level of income inequality. Nevertheless, the data presented here suggest an important role for organizational theory in linking market and institutional change to societal change by considering how firms react to external demands. Firms play a central role in how workers are matched to jobs and how they are rewarded for their labor. That these practices have important implications for how income is distributed in a region suggests that more attention be given to understanding how changes in corporate organization affect labor market outcomes. 
Figure 1. Wage Compression and State-level Income Inequality

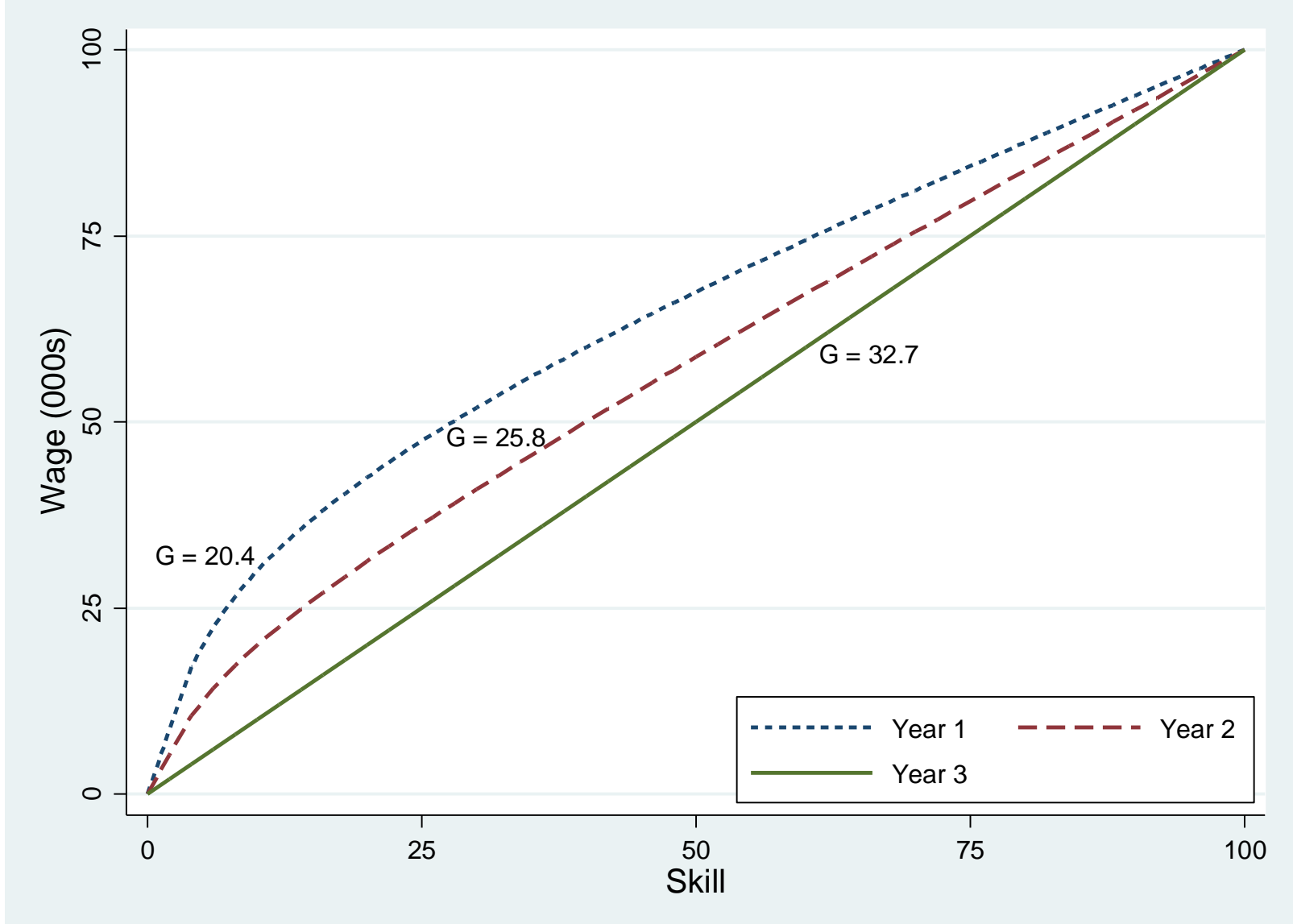


Figure 2. Interaction Plots of Significant Interactions
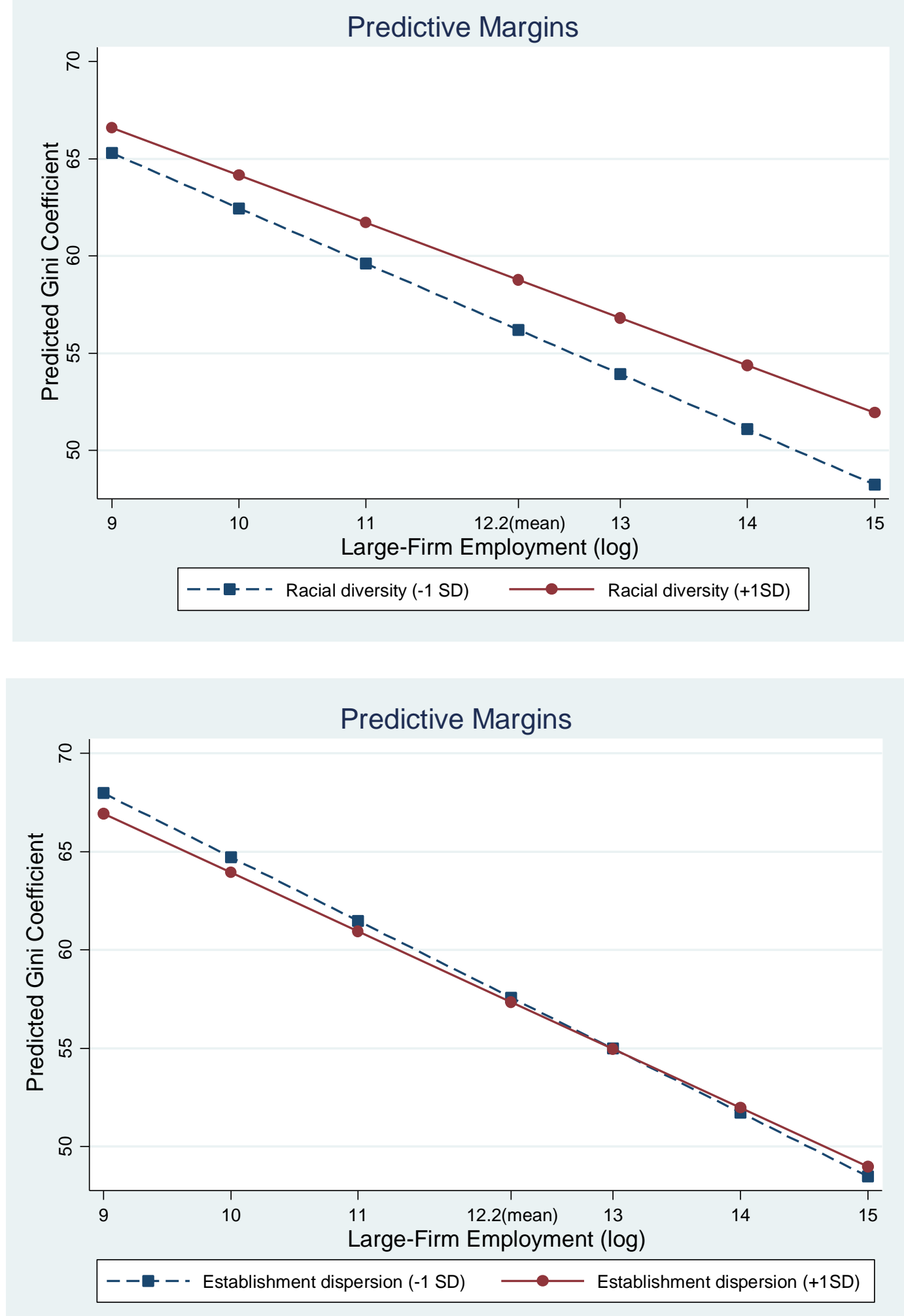
Figure 3. Change in Gini Coefficient and Change in the Proportion of Employment in Large Firms, 1978-2008

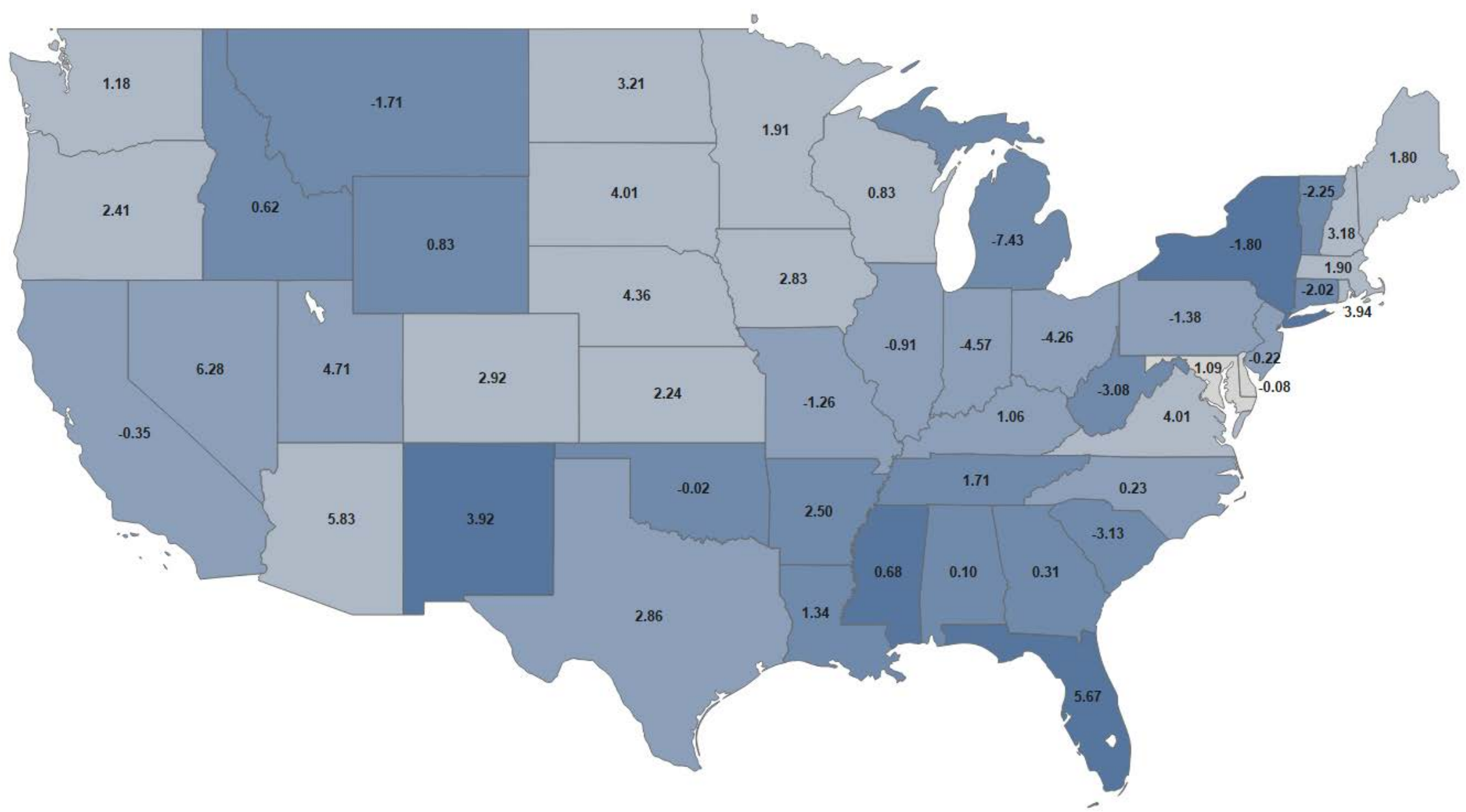

Gini coefficient change

$14.00 \quad 29.00$ 
Table 1. Means, standard deviations, and data source of variables in the analysis of state-level income inequality $(N=1,488)$

\begin{tabular}{|c|c|c|c|c|c|}
\hline Variables & Mean & S.D. & Min. & Max & Source \\
\hline Gini coefficient & 57.28 & 7.31 & 43.90 & 87.78 & Frank (2009) \\
\hline Large-firm employment (log) & 12.20 & 1.21 & 9.31 & 14.75 & EEO-1 \\
\hline Large-firm racial diversity & 49.35 & 10.37 & 24.80 & 81.58 & EEO-1 \\
\hline Large-firm establishment dispersion & 93.96 & 3.60 & 57.78 & 98.84 & EEO-1 \\
\hline Labor force (log) & 14.42 & 0.99 & 12.37 & 16.85 & BLS (State \& Area Employment, Hours, \& Earnings) \\
\hline GDP per capita (log) & 10.04 & 0.47 & 8.87 & 11.17 & BEA (Regional Economic Accounts) \\
\hline Black employment (\%) & 10.61 & 9.41 & 0.24 & 43.20 & EEO-1 \\
\hline Urban population (\%) & 68.65 & 14.57 & 32.20 & 94.46 & U.S. Census (Urban Percentage of the Population for States, Historical) \\
\hline Large-firm service employment (\%) & 39.80 & 8.64 & 17.14 & 65.98 & EEO-1 \\
\hline Government employment (\%) & 16.01 & 3.03 & 10.11 & 25.72 & U.S. Census (County Business Patterns) \\
\hline Manufacturing employment (\%) & 19.49 & 8.19 & 4.01 & 42.81 & U.S. Census (County Business Patterns) \\
\hline Retail employment (\%) & 19.32 & 4.12 & 11.18 & 28.75 & U.S. Census (County Business Patterns) \\
\hline College graduates (\%) & 14.23 & 4.08 & 6.44 & 30.56 & Frank $(2009)^{1}$ \\
\hline Foreign direct investment $(\log )$ & 8.33 & 1.20 & 3.86 & 11.16 & BEA (Activities of U.S. Affiliates of Foreign Multinational Enterprises) \\
\hline Union density (\%) & 14.55 & 6.75 & 2.30 & 38.30 & Hirsch and Macpherson (2003) \\
\hline Unemployment (\%) & 5.73 & 1.95 & 2.30 & 17.40 & BLS (Local Area Unemployment Statistics) \\
\hline Democrats in state legislature (\%) & 56.00 & 16.94 & 10.71 & 98.10 & Klarner (2014) \\
\hline Tax rate $(\%)$ & 44.31 & 8.44 & 28.00 & 75.94 & NBER \\
\hline Minimum wage & 3.13 & 0.38 & 2.55 & 4.08 & TPC; DOL (Wage \& Hour Division) \\
\hline Government transfers per capita (log) & 4.75 & 0.19 & 4.18 & 5.37 & BEA (Regional Economic Accounts) \\
\hline Patents (per 000s) & 0.42 & 0.39 & 0.02 & 2.72 & Lai et al. (2015) \\
\hline
\end{tabular}


Table 2. Correlation matrix

\begin{tabular}{|c|c|c|c|c|c|c|c|c|c|c|c|c|}
\hline \multicolumn{2}{|c|}{ Variables } & \multirow{2}{*}{$\begin{array}{l}1 \\
1\end{array}$} & \multirow[t]{2}{*}{2} & \multirow[t]{2}{*}{3} & \multirow[t]{2}{*}{4} & \multirow[t]{2}{*}{5} & \multirow[t]{2}{*}{6} & \multirow[t]{2}{*}{7} & \multirow[t]{2}{*}{8} & \multirow[t]{2}{*}{9} & \multirow[t]{2}{*}{10} & \multirow[t]{2}{*}{11} \\
\hline 1 & Gini coefficient & & & & & & & & & & & \\
\hline 2 & Large-firm employment (log) & 0.12 & 1 & & & & & & & & & \\
\hline 3 & Large-firm racial diversity & 0.77 & 0.34 & 1 & & & & & & & & \\
\hline 4 & Large-firm establishment dispersion & -0.30 & -0.27 & -0.17 & 1 & & & & & & & \\
\hline 5 & Labor force $(\log )$ & 0.15 & 0.98 & 0.34 & -0.23 & 1 & & & & & & \\
\hline 6 & GDP per capita (log) & 0.77 & 0.24 & 0.83 & -0.19 & 0.24 & 1 & & & & & \\
\hline 7 & Black employment (\%) & 0.09 & 0.45 & 0.32 & -0.01 & 0.40 & 0.08 & 1 & & & & \\
\hline 8 & Urban population (\%) & 0.12 & 0.54 & 0.31 & -0.17 & 0.54 & 0.29 & 0.03 & 1 & & & \\
\hline 9 & Large-firm service employment (\%) & 0.56 & -0.04 & 0.58 & -0.03 & 0.03 & 0.59 & -0.16 & 0.34 & 1 & & \\
\hline 10 & Government employment (\%) & -0.23 & -0.46 & -0.30 & 0.22 & -0.41 & -0.46 & 0.09 & -0.33 & -0.22 & 1 & \\
\hline 11 & Manufacturing employment (\%) & -0.49 & 0.17 & -0.52 & -0.09 & 0.10 & -0.55 & 0.19 & -0.28 & -0.71 & -0.07 & 1 \\
\hline 12 & Retail employment (\%) & -0.45 & -0.42 & -0.67 & 0.19 & -0.37 & -0.63 & -0.24 & -0.27 & -0.26 & 0.51 & 0.18 \\
\hline 13 & College graduates (\%) & 0.56 & 0.23 & 0.58 & -0.18 & 0.25 & 0.79 & -0.03 & 0.38 & 0.49 & -0.44 & -0.44 \\
\hline 14 & Foreign direct investment (log) & 0.30 & 0.83 & 0.50 & -0.16 & 0.84 & 0.46 & 0.43 & 0.47 & 0.16 & -0.34 & -0.13 \\
\hline 15 & Union density (\%) & -0.42 & 0.15 & -0.44 & -0.07 & 0.15 & -0.34 & -0.26 & 0.25 & -0.25 & -0.21 & 0.29 \\
\hline 16 & Unemployment (\%) & -0.32 & 0.10 & -0.33 & 0.06 & 0.10 & -0.49 & 0.11 & -0.03 & -0.40 & 0.22 & 0.31 \\
\hline 17 & Democrats in state legislature (\%) & -0.24 & 0.15 & -0.13 & 0.01 & 0.13 & -0.30 & 0.45 & -0.06 & -0.29 & 0.14 & 0.33 \\
\hline 18 & Tax rate $(\%)$ & -0.54 & -0.10 & -0.46 & 0.09 & -0.12 & -0.59 & -0.07 & -0.07 & -0.40 & 0.21 & 0.35 \\
\hline 19 & Minimum wage & -0.50 & -0.07 & -0.46 & 0.02 & -0.08 & -0.56 & -0.13 & 0.04 & -0.38 & 0.12 & 0.35 \\
\hline 20 & Government transfers per capita (log) & 0.46 & 0.16 & 0.42 & -0.12 & 0.17 & 0.52 & -0.02 & 0.00 & 0.31 & -0.44 & -0.14 \\
\hline 21 & Patents (per 000s) & 0.33 & 0.21 & 0.37 & -0.20 & 0.19 & 0.57 & -0.13 & 0.31 & 0.24 & -0.51 & -0.21 \\
\hline
\end{tabular}

\begin{tabular}{|c|c|c|c|c|c|c|c|c|c|c|c|}
\hline \multicolumn{2}{|c|}{ Variables } & 12 & 13 & 14 & 15 & 16 & 17 & 18 & 19 & 20 & 21 \\
\hline 12 & Retail employment (\%) & 1 & & & & & & & & & \\
\hline 13 & College graduates (\%) & -0.52 & 1 & & & & & & & & \\
\hline 14 & Foreign direct investment (log) & -0.42 & 0.31 & 1 & & & & & & & \\
\hline 15 & Union density (\%) & 0.10 & -0.15 & -0.01 & 1 & & & & & & \\
\hline 16 & Unemployment (\%) & 0.29 & -0.45 & 0.07 & 0.37 & 1 & & & & & \\
\hline 17 & Democrats in state legislature (\%) & 0.06 & -0.22 & 0.09 & 0.09 & 0.33 & 1 & & & & \\
\hline 18 & Tax rate $(\%)$ & 0.16 & -0.38 & -0.31 & 0.33 & 0.26 & 0.16 & 1 & & & \\
\hline 19 & Minimum wage & 0.14 & -0.28 & -0.28 & 0.46 & 0.23 & 0.25 & 0.68 & 1 & & \\
\hline 20 & Government transfers per capita (log) & -0.41 & 0.37 & 0.27 & 0.15 & 0.07 & -0.02 & -0.31 & -0.28 & 1 & \\
\hline 21 & Patents (per 000s) & -0.51 & 0.66 & 0.25 & 0.04 & -0.27 & -0.20 & -0.17 & -0.02 & 0.31 & 1 \\
\hline
\end{tabular}


Table 3. Fixed effects regressions on state income inequality, 1978-2008

\begin{tabular}{|c|c|c|c|c|c|}
\hline Variables & M1 & M2 & M3 & M4 & M5 \\
\hline Large-firm employment (log) & -- & $\begin{array}{l}-2.886 * * * \\
(0.474)\end{array}$ & $\begin{array}{l}-3.034 * * * \\
(0.496)\end{array}$ & $\begin{array}{l}-2.644 * * * \\
(0.504)\end{array}$ & $\begin{array}{c}-3.121 * * * \\
(0.495)\end{array}$ \\
\hline Large-firm racial diversity & -- & -- & $\begin{array}{l}0.105^{* * *} \\
(0.025)\end{array}$ & $\begin{array}{c}0.124^{* * *} \\
(0.026)\end{array}$ & $\begin{array}{c}0.110^{* * *} \\
(0.025)\end{array}$ \\
\hline $\begin{array}{l}\text { Large-firm employment } \mathrm{x} \\
\text { Large-firm racial diversity }\end{array}$ & -- & -- & -- & $\begin{array}{c}0.019 * * * \\
(0.005)\end{array}$ & -- \\
\hline Large-firm establishment dispersion & -- & -- & $\begin{array}{l}-0.035 \\
(0.022)\end{array}$ & $\begin{array}{r}-0.039+ \\
(0.022)\end{array}$ & $\begin{array}{l}-0.030 \\
(0.022)\end{array}$ \\
\hline $\begin{array}{l}\text { Large-firm employment } \mathrm{x} \\
\text { Large-firm establishment dispersion }\end{array}$ & -- & -- & -- & -- & $\begin{array}{c}0.035^{* *} \\
(0.011)\end{array}$ \\
\hline Labor force (log) & $\begin{array}{c}0.055 \\
(0.786)\end{array}$ & $\begin{array}{c}3.815^{* * *} \\
(0.992)\end{array}$ & $\begin{array}{l}3.710 * * * \\
(1.009)\end{array}$ & $\begin{array}{l}2.390^{*} \\
(1.063)\end{array}$ & $\begin{array}{c}3.936 * * * \\
(1.009)\end{array}$ \\
\hline GDP per capita (log) & $\begin{array}{l}-2.434^{*} \\
(0.995)\end{array}$ & $\begin{array}{r}-1.643+ \\
(0.991)\end{array}$ & $\begin{array}{l}-1.610 \\
(0.986)\end{array}$ & $\begin{array}{l}-0.947 \\
(0.996)\end{array}$ & $\begin{array}{r}-1.821+ \\
(0.985)\end{array}$ \\
\hline Black employment (\%) & $\begin{array}{l}-0.061 \\
(0.051)\end{array}$ & $\begin{array}{l}-0.049 \\
(0.050)\end{array}$ & $\begin{array}{l}-0.094+ \\
(0.051)\end{array}$ & $\begin{array}{l}-0.131^{*} \\
(0.051)\end{array}$ & $\begin{array}{l}-0.098+ \\
(0.051)\end{array}$ \\
\hline Urban population (\%) & $\begin{array}{c}0.012 \\
(0.035)\end{array}$ & $\begin{array}{c}0.025 \\
(0.034)\end{array}$ & $\begin{array}{c}0.005 \\
(0.034)\end{array}$ & $\begin{array}{c}0.002 \\
(0.034)\end{array}$ & $\begin{array}{l}0.000 \\
(0.034)\end{array}$ \\
\hline Large-firm service employment (\%) & $\begin{array}{c}0.010 \\
(0.014)\end{array}$ & $\begin{array}{l}-0.019 \\
(0.015)\end{array}$ & $\begin{array}{l}-0.022 \\
(0.015)\end{array}$ & $\begin{array}{c}0.006 \\
(0.017)\end{array}$ & $\begin{array}{l}-0.022 \\
(0.015)\end{array}$ \\
\hline Government employment (\%) & $\begin{array}{c}0.321^{* * *} \\
(0.086)\end{array}$ & $\begin{array}{c}0.281^{* * *} \\
(0.085)\end{array}$ & $\begin{array}{c}0.267^{* *} \\
(0.084)\end{array}$ & $\begin{array}{l}0.195 * \\
(0.086)\end{array}$ & $\begin{array}{c}0.281^{* * *} \\
(0.084)\end{array}$ \\
\hline Manufacturing employment (\%) & $\begin{array}{c}-0.163^{* * *} \\
(0.025)\end{array}$ & $\begin{array}{c}-0.104 * * * \\
(0.026)\end{array}$ & $\begin{array}{c}-0.119 * * * \\
(0.027)\end{array}$ & $\begin{array}{c}-0.089 * * \\
(0.028)\end{array}$ & $\begin{array}{c}-0.123^{* * *} \\
(0.027)\end{array}$ \\
\hline Retail employment (\%) & $\begin{array}{c}0.033 \\
(0.049)\end{array}$ & $\begin{array}{c}0.060 \\
(0.049)\end{array}$ & $\begin{array}{l}0.093+ \\
(0.049)\end{array}$ & $\begin{array}{l}0.094+ \\
(0.049)\end{array}$ & $\begin{array}{l}0.096+ \\
(0.049)\end{array}$ \\
\hline College graduates (\%) & $\begin{array}{c}-0.114 * * \\
(0.043)\end{array}$ & $\begin{array}{c}-0.104 * \\
(0.043)\end{array}$ & $\begin{array}{l}-0.108^{*} \\
(0.043)\end{array}$ & $\begin{array}{l}-0.104^{*} \\
(0.042)\end{array}$ & $\begin{array}{c}-0.102 * \\
(0.042)\end{array}$ \\
\hline Foreign direct investment (log) & $\begin{array}{c}0.879 * * * \\
(0.165)\end{array}$ & $\begin{array}{c}1.007^{* * *} \\
(0.164)\end{array}$ & $\begin{array}{c}0.986 * * * \\
(0.163)\end{array}$ & $\begin{array}{c}0.890^{* * *} \\
(0.165)\end{array}$ & $\begin{array}{c}0.980^{* * *} \\
(0.163)\end{array}$ \\
\hline Union density (\%) & $\begin{array}{c}-0.010 \\
(0.028)\end{array}$ & $\begin{array}{c}0.016 \\
(0.028)\end{array}$ & $\begin{array}{c}0.017 \\
(0.028)\end{array}$ & $\begin{array}{c}0.023 \\
(0.028)\end{array}$ & $\begin{array}{c}0.010 \\
(0.028)\end{array}$ \\
\hline Unemployment (\%) & $\begin{array}{l}-0.086 \\
(0.053)\end{array}$ & $\begin{array}{c}-0.064 \\
(0.052)\end{array}$ & $\begin{array}{l}-0.062 \\
(0.052)\end{array}$ & $\begin{array}{l}-0.066 \\
(0.052)\end{array}$ & $\begin{array}{l}-0.055 \\
(0.052)\end{array}$ \\
\hline Democrats in state legislature (\%) & $\begin{array}{c}-0.039 * * * \\
(0.007)\end{array}$ & $\begin{array}{c}-0.038^{* * *} \\
(0.007)\end{array}$ & $\begin{array}{c}-0.040 * * * \\
(0.007)\end{array}$ & $\begin{array}{c}-0.033^{* * *} \\
(0.007)\end{array}$ & $\begin{array}{c}-0.042^{* * *} \\
(0.007)\end{array}$ \\
\hline State income tax rate (\%) & $\begin{array}{l}-0.050 \\
(0.075)\end{array}$ & $\begin{array}{l}-0.086 \\
(0.074)\end{array}$ & $\begin{array}{l}-0.069 \\
(0.074)\end{array}$ & $\begin{array}{l}-0.079 \\
(0.074)\end{array}$ & $\begin{array}{l}-0.067 \\
(0.074)\end{array}$ \\
\hline Minimum wage & $\begin{array}{l}-0.744^{*} \\
(0.320)\end{array}$ & $\begin{array}{l}-0.750 * \\
(0.316)\end{array}$ & $\begin{array}{c}-1.007 * * \\
(0.323)\end{array}$ & $\begin{array}{c}-1.040 * * \\
(0.322)\end{array}$ & $\begin{array}{c}-0.913 * * \\
(0.324)\end{array}$ \\
\hline Government transfers per capita (log) & $\begin{array}{l}1.859+ \\
(1.097)\end{array}$ & $\begin{array}{l}2.162^{*} \\
(1.084)\end{array}$ & $\begin{array}{l}2.084+ \\
(1.078)\end{array}$ & $\begin{array}{c}3.027^{* *} \\
(1.101)\end{array}$ & $\begin{array}{l}1.778+ \\
(1.079)\end{array}$ \\
\hline Patents (per 000s) & $\begin{array}{c}0.166 \\
(0.246)\end{array}$ & $\begin{array}{l}-0.113 \\
(0.247)\end{array}$ & $\begin{array}{l}-0.060 \\
(0.258)\end{array}$ & $\begin{array}{c}0.075 \\
(0.259)\end{array}$ & $\begin{array}{l}-0.129 \\
(0.258)\end{array}$ \\
\hline Constant & $\begin{array}{c}49.763^{* * * *} \\
(2.180)\end{array}$ & $\begin{array}{c}51.030 * * * \\
(2.163) \\
\end{array}$ & $\begin{array}{c}52.181^{* * *} \\
(2.167) \\
\end{array}$ & $\begin{array}{c}53.140 * * * \\
(2.171) \\
\end{array}$ & $\begin{array}{c}52.014 * * * \\
(2.160) \\
\end{array}$ \\
\hline Observations & 1,488 & 1,488 & 1,488 & 1,488 & 1,488 \\
\hline States & 48 & 48 & 48 & 48 & 48 \\
\hline R-squared & 0.81 & 0.86 & 0.88 & 0.89 & 0.88 \\
\hline Year dummies & Yes & Yes & Yes & Yes & Yes \\
\hline Years of analysis & $1978-2008$ & 1978-2008 & $1978-2008$ & $1978-2008$ & 1978-2008 \\
\hline
\end{tabular}

${ }^{* * *} \mathrm{p}<0.001,{ }^{* *} \mathrm{p}<0.01,{ }^{*} \mathrm{p}<0.05,+\mathrm{p}<0.10$. Standard errors in parentheses. 
Table 4. Fixed effects regressions using the ratio of large-firm employment to the non-farm labor force, 1978-2008

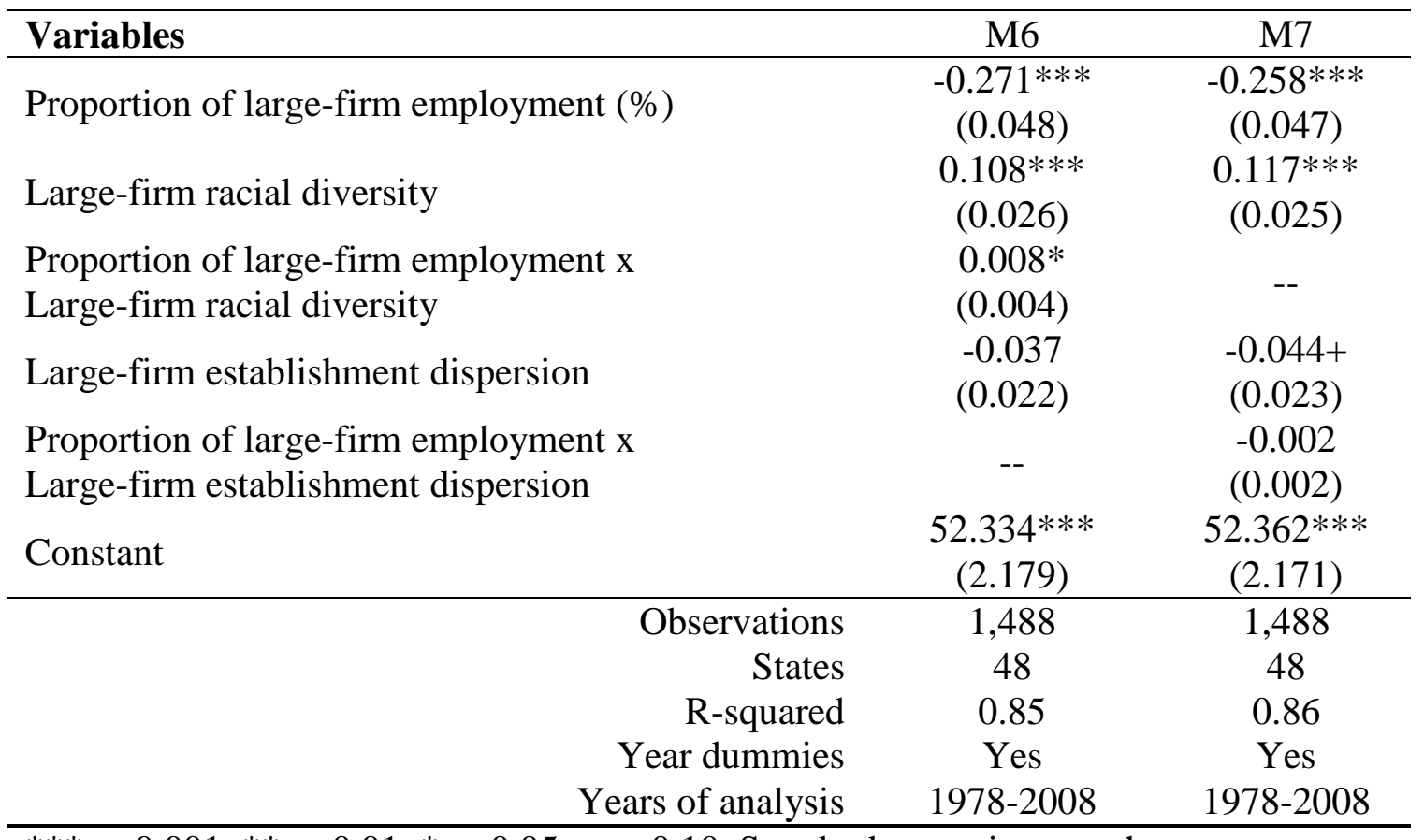

*** $\mathrm{p}<0.001,{ }^{* *} \mathrm{p}<0.01,{ }^{*} \mathrm{p}<0.05,+\mathrm{p}<0.10$. Standard errors in parentheses. 
Table 5. Fixed effects regressions on total annual wage and salary income deciles, 1978-2004

\begin{tabular}{|c|c|c|c|c|c|c|c|c|c|c|}
\hline \multirow[b]{2}{*}{ Variables } & M8 & M9 & M10 & M11 & M12 & M13 & M14 & M15 & M16 & M17 \\
\hline & \multicolumn{2}{|c|}{ 10th percentile } & \multicolumn{2}{|c|}{ 30th percentile } & \multicolumn{2}{|c|}{ 50th percentile } & \multicolumn{2}{|c|}{ 70th percentile } & \multicolumn{2}{|c|}{ 90th percentile } \\
\hline Large-firm employment (log) & $\begin{array}{c}0.033 \\
(0.024)\end{array}$ & $\begin{array}{c}0.034 \\
(0.025)\end{array}$ & $\begin{array}{c}0.052 * * * \\
(0.015)\end{array}$ & $\begin{array}{c}0.051^{* *} \\
(0.016)\end{array}$ & $\begin{array}{c}0.042 * * * \\
(0.012)\end{array}$ & $\begin{array}{c}0.040 * * * \\
(0.012)\end{array}$ & $\begin{array}{l}0.033^{* *} \\
(0.012)\end{array}$ & $\begin{array}{l}0.030 * \\
(0.012)\end{array}$ & $\begin{array}{c}0.024 \\
(0.015)\end{array}$ & $\begin{array}{c}0.022 \\
(0.015)\end{array}$ \\
\hline Large-firm racial diversity & $\begin{array}{l}-0.002 \\
(0.001)\end{array}$ & $\begin{array}{l}-0.000 \\
(0.001)\end{array}$ & $\begin{array}{l}-0.001 \\
(0.001)\end{array}$ & $\begin{array}{c}0.000 \\
(0.001)\end{array}$ & $\begin{array}{l}-0.001 \\
(0.001)\end{array}$ & $\begin{array}{l}-0.000 \\
(0.001)\end{array}$ & $\begin{array}{l}-0.000 \\
(0.001)\end{array}$ & $\begin{array}{c}0.000 \\
(0.001)\end{array}$ & $\begin{array}{c}0.001 \\
(0.001)\end{array}$ & $\begin{array}{c}0.001 \\
(0.001)\end{array}$ \\
\hline $\begin{array}{l}\text { Large-firm employment x } \\
\text { Large-firm racial diversity }\end{array}$ & $\begin{array}{c}-0.002^{* * *} \\
(0.000)\end{array}$ & -- & $\begin{array}{c}-0.001 * * * \\
(0.000)\end{array}$ & -- & $\begin{array}{c}-0.001 * * * \\
(0.000)\end{array}$ & -- & $\begin{array}{l}-0.001^{*} \\
(0.000)\end{array}$ & -- & $\begin{array}{c}0.000 \\
(0.000)\end{array}$ & -- \\
\hline Large-firm establishment dispersion & $\begin{array}{l}-0.001 \\
(0.001)\end{array}$ & $\begin{array}{l}-0.001 \\
(0.001)\end{array}$ & $\begin{array}{l}-0.001 \\
(0.001)\end{array}$ & $\begin{array}{l}-0.001 \\
(0.001)\end{array}$ & $\begin{array}{l}-0.001 \\
(0.001)\end{array}$ & $\begin{array}{l}-0.001+ \\
(0.001)\end{array}$ & $\begin{array}{l}-0.001 \\
(0.001)\end{array}$ & $\begin{array}{l}-0.001 \\
(0.001)\end{array}$ & $\begin{array}{l}-0.001 \\
(0.001)\end{array}$ & $\begin{array}{l}-0.001 \\
(0.001)\end{array}$ \\
\hline $\begin{array}{l}\text { Large-firm employment } \mathrm{x} \\
\text { Large-firm establishment dispersion }\end{array}$ & -- & $\begin{array}{l}-0.000 \\
(0.001)\end{array}$ & -- & $\begin{array}{c}0.001 \\
(0.001)\end{array}$ & -- & $\begin{array}{c}0.001 \\
(0.001)\end{array}$ & -- & $\begin{array}{c}0.000 \\
(0.000)\end{array}$ & -- & $\begin{array}{c}0.001 \\
(0.001)\end{array}$ \\
\hline Constant & $\begin{array}{c}9.597 * * * \\
(0.108) \\
\end{array}$ & $\begin{array}{c}9.665^{* * *} \\
(0.110) \\
\end{array}$ & $\begin{array}{c}10.145^{* * *} \\
(0.067) \\
\end{array}$ & $\begin{array}{c}10.198 * * * \\
(0.069) \\
\end{array}$ & $\begin{array}{c}10.337 * * * \\
(0.054) \\
\end{array}$ & $\begin{array}{c}10.373 * * * \\
(0.054) \\
\end{array}$ & $\begin{array}{c}10.615 * * * \\
(0.052) \\
\end{array}$ & $\begin{array}{c}10.631 * * * \\
(0.052)\end{array}$ & $\begin{array}{c}11.010 * * * \\
(0.067)\end{array}$ & $\begin{array}{c}11.003^{* * * *} \\
(0.066)\end{array}$ \\
\hline Observations & 1,296 & 1,296 & 1,296 & 1,296 & 1,296 & 1,296 & 1,296 & 1,296 & 1,296 & 1,296 \\
\hline States & 48 & 48 & 48 & 48 & 48 & 48 & 48 & 48 & 48 & 48 \\
\hline R-squared & 0.44 & 0.46 & 0.52 & 0.48 & 0.62 & 0.56 & 0.76 & 0.75 & 0.82 & 0.82 \\
\hline Year dummies & Yes & Yes & Yes & Yes & Yes & Yes & Yes & Yes & Yes & Yes \\
\hline Years of analysis & 1978-2004 & 1978-2004 & $1978-2004$ & 1978-2004 & 1978-2004 & 1978-2004 & 1978-2004 & 1978-2004 & 1978-2004 & 1978-2004 \\
\hline
\end{tabular}

*** $\mathrm{p}<0.001,{ }^{* *} \mathrm{p}<0.01, * \mathrm{p}<0.05,+\mathrm{p}<0.10$. Standard errors in parentheses. 


\section{REFERENCES}

\section{Adams, J. S.}

1963 "Toward an Understanding of Inequity." Journal of Abnormal Psychology, 67: 422-436.

Aghion, P., Akcigit, U., Bergeaud, A., Blundell, R., and Hémous, D.

2015 "Innovation and Top Income Inequality." NBER Working Paper No. 21247: 1-57.

Aiken, L. S., and West, S. G.

1991 Multiple Regression: Testing and Interpreting Interactions Thousand Oaks, CA: Sage Publications.

Akerlof, G. A., and Yellen, J. L.

1988 "Fairness and Unemployment." American Economic Review, 78: 44-49.

Alderfer, C. P.

1977 "Group and intergroup relations." In J. R. Hackman, and J. L. Suttle (eds.), Improving life at work: 227-296. Santa Monica, CA: Goodyear Publishing Company.

Alderson, A. S., and Nielsen, F.

2002 "Globalization and the great U-turn: Income inequality trends in 16 OECD countries." American Journal of Sociology, 107: 1244-1299.

Atkinson, A. B., Piketty, T., and Saez, E.

2011 "Top Incomes in the Long Run of History." Journal of Economic Literature, 49: 3-71.

Autor, D. H., Katz, L. F., and Kearney, M. S.

2008 "Trends in US wage inequality: Revising the revisionists." Review of Economics and Statistics, 90: 300-323.

Autor, D. H., Levy, F., and Murnane, R. J.

2003 "The skill content of recent technological change: An empirical exploration." Quarterly Journal of Economics, 118: 1279-1333.

Avent-Holt, D., and Tomaskovic-Devey, D.

2014 "A Relational Theory of Earnings Inequality." American Behavioral Scientist, 58: 379399.

Bacolod, M., Blum, B. S., and Strange, W. C.

2009 "Skills in the city." Journal of Urban Economics, 65: 136-153.

Baker, G. P., Jensen, M. C., and Murphy, K. J.

1988 "Compensation and Incentives: Practice Vs Theory." Journal of Finance, 43: 593-616.

Bandiera, O., Barankay, I., and Rasul, I. 
2007 "Incentives for managers and inequality among workers: Evidence from a firm-level experiment." Quarterly Journal of Economics, 122: 729-773.

Baron, J. N.

1984 "Organizational Perspectives on Stratification." Annual Review of Sociology, 10: 37-69.

Baron, J. N., and Bielby, W. T.

1980 "Bringing the Firms Back in: Stratification, Segmentation, and the Organization of

Work." American Sociological Review, 45: 737-765.

Barrilleaux, C., and Davis, B. C.

2003 "Explaining state-level variations in levels and change in the distribution of income in the United States, 1978-1990." American Politics Research, 31: 280-300.

Bartling, B., and von Siemens, F. A.

2010 "The intensity of incentives in firms and markets: Moral hazard with envious agents." Labour Economics, 17: 598-607.

Batt, R.

2001 "Explaining wage inequality in telecommunications services: Customer segmentation, human resource practices, and union decline." Industrial \& Labor Relations Review, 54: 425449.

Beck, E. M., Horan, P. M., and Tolbert, C. M.

1978 "Stratification in a Dual Economy: Sectoral Model of Earnings Determination." American Sociological Review, 43: 704-720.

Becker, G. S.

1964 Human capital: A theoretical and empirical analysis, with special reference to education. New York: National Bureau of Economic Research.

Beer, M., Spector, B., and Lawrence, P. R.

1984 Managing Human Assets. New York: Free Press.

Bentele, K. G., and Kenworthy, L.

2013 "Globalization and Earnings Inequality in the United States." In R. Rycroft (ed.), The Economics of Inequality, Poverity and Disrimination in the 21st Century: 343-358. Santa Barbara, CA: Prager.

Bidwell, M. J.

2013 "What Happened to Long-Term Employment? The Role of Worker Power and Environmental Turbulence in Explaining Declines in Worker Tenure." Organization Science, 24: 1061-1082.

Bidwell, M. J., Briscoe, F., Fernandez-Mateo, I., and Sterling, A. 
2013 "The Employment Relationship and Inequality: How and Why Changes in Employment Practices are Reshaping Rewards in Organizations." Academy of Management Annals, 7: 61121.

Blanton, H., Crocker, J., and Miller, D. T.

2000 "The effects of in-group versus out-group social comparison on self-esteem in the context of a negative stereotype." Journal of Experimental Social Psychology, 36: 519-530.

Boxall, P., and Purcell, J.

2011 Strategy and Human Resource Management, 3 ed. New York: Palgrave Macmillan.

Brown, C., and Medoff, J.

1989 "The Employer Size Wage Effect." Journal of Political Economy, 97: 1027-1059.

\section{Cappelli, P. H.}

1999 The New Deal at Work: Managing the Market-Driven Workforce. Boston, MA: Harvard University Press.

Cappelli, P. H.

2001 "Assessing the Decline of Internal Labor Markets." In I. Berg, and A. L. Kalleberg (eds.), Sourcebook of labor markets: Evolving structures and processes: 207-245. New York: Kluwer Academic/Plenum Publishers.

Cappelli, P. H., and Chauvin, K. W.

1991 "An Interplant Test of the Efficiency Wage Hypothesis." Quarterly Journal of Economics, 106: 769-787.

Cappelli, P. H., and Keller, J.

2013 "A Study of the Extent and Potential Causes of Alternative Employment Arrangements." ILR Review, 66: 874-901.

\section{Carnahan, S., Agarwal, R., and Campbell, B. A.}

2012 "Heterogeneity in turnover: The effect of relative compensation dispersion of firms on the mobility and entrepreneurship of extreme performers." Strategic Management Journal, 33: 1411-1430.

Carrington, W. J., and Troske, K. R.

1998 "Interfirm segregation and the black/white wage gap." Journal of Labor Economics, 16: 231-260.

Carroll, G. R., and Hannan, M. T.

2000 The Demography of Corporations and Industries. Princeton, NJ: Princeton University Press.

\section{Cobb, J. A.}


2015 "Risky business: Firms' shifting of retirement risk and the decline of defined benefit pension plans." Organization Science, 26: 1332-1350.

Cobb, J. A.

2016 "How firms shape income inequality: Stakeholder power, executive decision-making, and the structuring of employment relationships." Academy of Management Review, 41: 324-348.

Cobb, J. A., Wry, T., and Zhao, E. Y.

2016 "Funding financial inclusion: Institutional logics and the contextual contingency of funding for microfinance organizations." Academy of Management Journal, Forthcoming.

Cohen, P. N., and Huffman, M. L.

2007 "Black under-representation in management across US labor markets." Annals of the American Academy of Political and Social Science, 609: 181-199.

Cohn, A., Fehr, E., Herrmann, B., and Schneider, F.

2014 "Social Comparison and Effort Provision: Evidence from a Field Experiment." Journal of the European Economic Association, 12: 877-898.

Davis, G. F.

2009a Managed by Markets: How Finance Reshaped America. New York: Oxford University Press USA.

Davis, G. F.

2009b "The rise and fall of finance and the end of the society of organizations." Academy of Management Perspectives 23: 27-44.

Davis, G. F., and Cobb, J. A.

2010 "Corporations and economic inequality around the world: the paradox of hierarchy."

Research in Organizational Behavior, 30: 35-53.

Davis, G. F., and Stout, S. K.

1992 "Organization Theory and the Market for Corporate Control: A Dynamic Analysis of the Characteristics of Large Takeover Targets, 1980-1990." Administrative Science Quarterly, 37: 305-633.

DiPrete, T. A., Eirich, G. M., and Pittinsky, M.

2010 "Compensation Benchmarking, Leapfrogs, and the Surge in Executive Pay." American Journal of Sociology, 115: 1671-1712.

Doeringer, P., and Piore, M. J.

1971 Internal Labor Markets and Manpower Analysis. Lexington, MA: D.C. Heath and Company.

Dube, A., and Kaplan, E. 
2010 "Does Outsourcing Reduce Wages in the Low-Wage Service Occupations? Evidence from Janitors and Guards." Industrial \& Labor Relations Review, 63: 287-306.

Feldman, E. R.

2014 "Legacy Divestitures: Motives and Implications." Organization Science, 25: 815-832.

Festinger, L.

1954 "A theory of social comparison processes." Human Relations, 7: 117-140.

Festinger, L., Schachter, S., and Back, K. W.

1950 Social Pressures in Informal Groups: A Study of Human Factors in Housing. New York: Harper.

Frank, M. W.

2009 "Inequality and Growth in the United States: Evidence from a New State-Level Panel of Income Inequality Measures." Economic Inquiry, 47: 55-68.

Galbraith, J. K., and Hale, J. T.

2008 "State Income Inequality and Presidential Election Turnout and Outcomes." Social Science Quarterly, 89: 887-901.

Garen, J. E.

1985 "Worker Heterogeneity, Job Screening, and Firm Size." Journal of Political Economy, 93: 715-739.

Gibson, D. E., and Lawrence, B. S.

2010 "Women's and Men's Career Referents: How Gender Composition and Comparison Level Shape Career Expectations." Organization Science, 21: 1159-1175.

Gino, F., and Pierce, L.

2010 "Lying to Level the Playing Field: Why People May Dishonestly Help or Hurt Others to Create Equity." Journal of Business Ethics, 95: 89-103.

Goldin, C., and Katz, L. F.

2008 The race between education and technology. Cambridge, MA: Harvard University Press.

Goodman, P. S.

1977 "Social comparison processes in organizations." In B. M. Staw, and G. R. Salancik (eds.), New directions in organizational behavior: 97-132. Chicago: St. Claire Press.

\section{Granovetter, $M$.}

1981 "Toward a Sociological Theory of Income Differences." In I. Berg (ed.), Sociological Perspectives on Labor Markets: 11-47. New York: Academic Press.

\section{Groshen, E. L.}


1991 "Sources of Intraindustry Wage Dispersion: How Much Do Employers Matter?" Quarterly Journal of Economics, 106: 869-884.

Groshen, E. L., and Levine, D. I.

1998 "The rise and decline(?) of U.S. internal labor markets." F. R. B. o. N. York, (ed.), Research Paper 9819: 1-51.

Harris, M. M., Anseel, F., and Lievens, F.

2008 "Keeping up with the joneses: A field study of the relationships among upward, lateral, and downward comparisons and pay level satisfaction." Journal of Applied Psychology, 93: 665673.

Harrison, D. A., and Klein, K. J.

2007 "What's the difference? Diversity constructs as separation, variety, or disparity in organizations." Academy of Management Review, 32: 1199-1228.

Hedström, P., and Swedberg, R.

1998 "Social mechanisms: An introductory essay." In P. Hedström, and R. Swedberg (eds.), Social Mechanisms: An Analytical Approach to Social Theory: 1-31: Cambridge University Press.

Hirsch, B. T., and Macpherson, D. A.

2003 "Union Membership and Coverage Database from the Current Population Survey: Note." Industrial \& Labor Relations Review, 56: 349-354.

Hirsh, C. E., and Kornrich, S.

2008 "The Context of Discrimination: Workplace Conditions, Institutional Environments, and Sex and Race Discrimination Charges." American Journal of Sociology, 113: 1394-1432.

Hollister, M. N.

2004 "Does firm size matter anymore? The new economy and firm size wage effects." American Sociological Review, 69: 659-676.

Huffman, M. L., and Cohen, P. N.

2004 "Racial wage inequality: Job segregation and devaluation across US labor markets." American Journal of Sociology, 109: 902-936.

Jensen, M. C.

1993 "The Modern Industrial-Revolution, Exit, and the Failure of Internal Control-Systems." Journal of Finance, 48: 831-880.

Jonish, J. E., and Kau, J. B.

1973 "State Differentials in Income Inequality." Review of Social Economy, 31: 179-190.

Kalev, A., Dobbin, F. R., and Kelly, E. 
2006 "Best practices or best guesses? Assessing the efficacy of corporate affirmative action and diversity policies." American Sociological Review, 71: 589-617.

Kalleberg, A. L.

2009 "Precarious Work, Insecure Workers: Employment Relations in Transition." American Sociological Review, 74: 1-22.

Kalleberg, A. L., and Sørensen, A. B.

1979 "Sociology of Labor-Markets." Annual Review of Sociology, 5: 351-379.

Kalleberg, A. L., and Van Buren, M. E.

1994 "The Structure of Organizational Earnings Inequality." American Behavioral Scientist, 37: 930-947.

Kalleberg, A. L., and Van Buren, M. E.

1996 "Is bigger better? Explaining the relationship between organization size and job rewards." American Sociological Review, 61: 47-66.

Katz, L. F., and Autor, D. A.

1999 "Changes in the Wage Structure and Earnings Inequality." In J. Brynjolfsson, and D.

Card (eds.), Handbook of Labor Economics: 1463-1555. Amsterdam: North Holland.

Kelly, N. J., and Witko, C.

2012 "Federalism and American Inequality." Journal of Politics, 74: 414-426.

Kennedy, P.

2003 A Guide to Econometrics, 5th ed. Cambridge, MA: The MIT Press.

Kenworthy, L., and Pontusson, J.

2005 "Rising inequality and the politics of redistribution in affluent countries." Perspectives on Politics, 3: 449-471.

Keppell, G., and Wickens, T. D.

2004 Design and Analysis: A Researcher's Handbook, 4 ed. Upper Saddle River, NJ: Prentice Hall.

Kim, J., Kogut, B., and Yang, J.-S.

2015 "Executive Compensation, Fat Cats and Best Athletes." American Sociological Review, 80: 299-328.

Klarner, C.

2014 "Klarner Politics." Indiana State University Center for Governmental Services.

Kulik, C. T., and Ambrose, M. L.

1992 "Personal and Situational Determinants of Referent Choice." Academy of Management Review, 17: 212-237. 
Lai, R., D'Amour, A., Yu, A., Sun, Y., and Fleming, L.

2015 "Disambiguation and Co-authorship Networks of the U.S. Patent Inventor Database (1975 - 2010)." Harvard Dataverse.

Lang, K., and Lehmann, J.-Y. K.

2012 "Racial Discrimination in the Labor Market: Theory and Empirics." Journal of Economic Literature, 50: 959-1006.

\section{Lansberg, I.}

1989 "Social Categorization, Entitlement, and Justice in Organizations: Contextual

Determinants and Cognitive Underpinnings." Human Relations, 41: 871-899.

Larkin, I., Pierce, L., and Gino, F.

2012 "The psychological costs of pay-for-performance: Implications for the strategic compensation of employees." Strategic Management Journal, 33: 1194-1214.

Lawrence, B. S.

2006 "Organizational reference groups: A missing perspective on social context." Organization Science, 17: 80-100.

Lazear, E. P.

1989 "Pay Equality and Industrial Politics." Journal of Political Economy, 97: 561-580.

Leicht, K. T.

2008 "Broken down by race and gender? Sociological explanations of new sources of earnings inequality." Annual Review of Sociology, 34: 237-255.

Lemieux, T., MacLeod, W. B., and Parent, D.

2009 "Performance Pay and Wage Inequality." Quarterly Journal of Economics, 124: 1-49.

Lepak, D. P., and Snell, S. A.

1999 "The human resource architecture: Toward a theory of human capital allocation and development." Academy of Management Journal, 24: 31-48.

Levy, F., and Murnane, R. J.

1992 "U.S. Earnings Levels and Earnings Inequality: A Review of Recent Trends and Proposed Explanations." Journal of Economic Literature, 30: 1333-1381.

\section{Lichtenstein, $\mathbf{N}$.}

2002 State of the Union: A Century of American Labor. Princeton, NJ: Princeton University

Press.

Lin, K.-H.

2013 "The Rise of Finance and Firm Employment Dynamics, 1982-2005." Available at SSRN: http://ssrn.com/abstract=2284507 1-52. 
Lin, K.-H., and Tomaskovic-Devey, D.

2013 "Financialization and US Income Inequality, 1970-2008." American Journal of Sociology, 118: 1284-1329.

Markovsky, B.

1985 "Toward a Multilevel Distributive Justice Theory." American Sociological Review, 50: 822-839.

\section{Martin, J.}

1981 "Relative deprivation: a theory of distributive injustice for an era of shrinking resources." In L. L. Cummings, and B. M. Staw (eds.), Research in Organizational Behavior: 53-107. Greenwich, CT: JAI Press.

McCall, L., and Percheski, C.

2010 "Income Inequality: New Trends and Research Directions." Annual Review of Sociology, 36: 329-347.

Mellow, W.

1982 "Employer Size and Wages." Review of Economics and Statistics, 64: 495-501.

Milgrom, P. R., and Roberts, J.

1988 "An Economic Approach to Influence Activities in Organizations." American Journal of Sociology, 94: S154-S179.

Molloy, R., Smith, C. L., and Wozniak, A.

2013 "Declining Migration Within the US: The Role of the Labor Market." F. R. Board, (ed.), Finance and Economics Discussion Series: 1-49. Washington, D.C.

Morris, M., and Western, B.

1999 "Inequality in earnings at the close of the twentieth century." Annual Review of Sociology, 25: 623-657.

Mouw, T., and Kalleberg, A. L.

2010 "Occupations and the Structure of Wage Inequality in the United States, 1980s to 2000s." American Sociological Review, 75: 402-431.

Nickerson, J. A., and Zenger, T. R.

2008 "Envy, Comparison Costs, and the Economic Theory of the Firm." Strategic Management Journal, 29: 1429-1449.

O'Shaughnessy, K. C., Levine, D. I., and Cappelli, P. H.

2001 "Changes in Managerial Pay Structures 1986-1992 and Rising Returns to Skill." Oxford Economic Papers, 3: 482-507.

Obloj, T., and Zenger, T. R. 
2015 "Incentives, Social Comparison Costs, and the Proximity of Envy's Object." HEC Paris Research Paper No. SPE-2015-1085. Available at SSRN: http://ssrn.com/abstract=2574248 1-35.

Oi, W. Y., and Idson, T. L.

1999 "Firm Size and wages." In O. Ashenfelter, and D. Card (eds.), Handbook of Labor Economics: 2165-2214. Amsterdam: Elsevier Science B.V.

Osterman, P. S.

1996 Broken ladders: managerial careers in the new economy. New York: Oxford University Press.

Partridge, M. D., Rickman, D. S., and Levernier, W.

1996 "Trends in US income inequality: Evidence from a panel of states." Quarterly Review of Economics and Finance, 36: 17-37.

Pfeffer, J.

2010 "Building Sustainable Organizations: The Human Factor." Academy of Management Perspectives, 24: 34-45.

Pfeffer, J., and Davis-Blake, A.

1990 "Determinants of Salary Dispersion in Organizations." Industrial Relations, 29: 38-57.

Pfeffer, J., and Davis-Blake, A.

1992 "Salary Dispersion, Location in the Salary Distribution, and Turnover among College Administrators." Industrial \& Labor Relations Review, 45: 753-763.

Pfeffer, J., and Langton, $N$.

1988 "Wage Inequality and the Organization of Work: the Case of Academic Departments." Administrative Science Quarterly, 33: 588-606.

Rawley, E., and Simcoe, T. S.

2010 "Diversification, Diseconomies of Scope, and Vertical Contracting: Evidence from the Taxicab Industry." Management Science, 56: 1534-1550.

Robinson, C. L., Tomaskovic-Devey, D., Zimmer, C., and Irvin Jr., M. W. 2005 "Studying race or ethnic and sex segregation at the establishment level: Methodological issues and substantive opportunities using EEO-1 reports." Work and Occupations, 32: 5-38.

\section{Rothschild-Whitt, J.}

1979 "Collectivist Organization: An Alternative to Rational-Bureaucratic Models." American Sociological Review, 44: 509-527.

Sanchez, J. I., and Levine, E. L.

2012 "The Rise and Fall of Job Analysis and the Future of Work Analysis." Annual Review of Psychology, Vol 63, 63: 397-425. 
Scott, W. R., and Davis, G. F.

2007 Organizations and organizing: rational, natural, and open systems perspectives. Upper Saddle River, NJ: Prentice Hall.

Song, J., Price, D. J., Guvenen, F., and Bloom, N.

2015 "Firming Up Inequality." Working Paper 21199. Cambridge, MA: National Bureau of Economic Research.

Sørensen, J. B.

2007 "Organizational diversity, labor markets, and wage inequality." American Behavioral Scientist, 50: 659-676.

Sørensen, J. B., and Sorenson, $O$.

2007 "Corporate demography and income inequality." American Sociological Review, 72:

766-783.

Sorenson, $\mathbf{O}$.

2003 "Social networks and industrial geography." Journal of Evolutionary Economics, 13: 513527.

\section{Tajfel, $\mathbf{H}$.}

1978 "Differentiation between social groups: Studies in the social psychology of intergroup relations." New York: Academic Press.

\section{Tilcsik, A.}

2011 "Pride and Prejudice: Employment Discrimination against Openly Gay Men in the United States." American Journal of Sociology, 117: 586-626.

Tilcsik, A., and Marquis, C.

2013 "Punctuated Generosity: How Mega-events and Natural Disasters Affect Corporate Philanthropy in US Communities." Administrative Science Quarterly, 58: 111-148.

\section{Useem, $M$.}

1996 "Corporate Education and Training." In C. Kaysen (ed.), The American corporation today: 292-326. New York: Oxford University Press.

\section{Volscho, J., Thomas W.}

2005 "Minimum Wages and Income Inequality in the American States, 1960-2000." Research in Social Stratification and Mobility, 23: 343-368.

Volscho, J., Thomas W., and Kelly, N. J.

2012 "The Rise of the Super-Rich: Power Resources, Taxes, Financial Markets, and the Dynamics of the Top 1 Percent, 1949 to 2008." American Sociological Review, 77: 679-699.

\section{Weinstein, N. D.}


1980 "Unrealistic Optimism About Future Life Events." Journal of Personality and Social Psychology, 39: 806-820.

Western, B., and Rosenfeld, J.

2011 "Unions, norms, and the rise in U.S. wage inequality." American Sociological Review, 76: 513-537.

\section{Whyte, W. H.}

1956 The Organization Man. New York: Simon \& Schuster.

Williams, K. Y., and O'Reilly, C. A.

1998 "Demography and diversity in organizations: A review of 40 years of research." Research in Organizational Behavior, 20: 77-140.

Williamson, O. E.

1985 The economic institutions of capitalism. New York: Free Press.

Wiseman, R. M.

2009 "On the use and misuse of ratios in strategic management research." In B. D. D., and D. J. Ketchen (eds.), Research Methodology in Strategy and Management 75-110. Bingley, UK:

Emerald Group Publishing Ltd.

Wood, $\mathbf{B}$.

1994 "From Social Inequality to Personal Entitlement: The Role of Social Comparisons, Legitimacy Appraisals, and Group Membership." Advances in Experimental Social Psychology, 26: 293-355.

Wooldridge, J. M.

2002 Econometric analysis of cross section and panel data. Cambridge, MA: The MIT Press.

Zenger, T. R., and Huang, J. X.

2009 "Limits to the scale and scope of the firm." In B. S. Silverman (ed.), Advances in Strategic Management: Emerald Group Publishing Ltd. 